ARAŞTIRMA MAKALESİ / RESEARCH ARTICLE

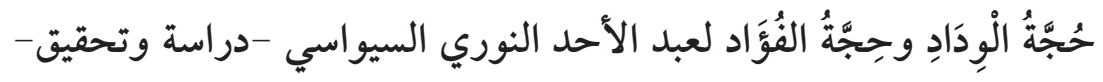

\title{
Abdülahad Nûrî Sivâsî ve Huccetü'l-Vidâd ve Hiccetü'l-Fu'âd Adlı Risalesinin Tahkik ve Tahlili
}

\author{
A Critical Edition and Analysis of Abdulaḥad Nūrī Sivāsīss \\ Hujjat al-Widād wa Hijjat al-Fu'ād
}

\begin{abstract}
Ali BENLi $\dot{I}^{*}$
Öz: Bu çalışmada Osmanlı mutasavvıflarından Abdülahad Nûrî (ö. 1061/1651) tarafından telif edilen Huccetü'l-vidâd ve hiccetü'l-fu'âd adlı risale tahkik edilip incelenmektedir. Meşhur mutasavviflar yetiştiren Sivâsîler ailesinden olan Abdülahad Nûrî eserlerinin çoğunu döneminde Kadızâdelilerin tasavvuf ehline yönelik eleştirilerine cevap olarak kaleme almıştır. Bunlar arasında Hz. Peygamber'in anne-babasının imanı, devranın caiz olması, zikrin fazileti ve faydaları, tayy-i mekân meselesi, vefat etmiş müminlere amellerin sevabını bağışlama meselesi, velilerin tasarrufu gibi konular zikredilebilir. İlahi sevgiyi konu edinen Huccetü’l-vidâd de müellifin döneminde tartışılan bir meseleye, kulun Allah’a, Allah’ın kula karşı sevgisinin niteliği konusunda tasavvuf ehlinin görüşlerini ortaya koyan bir eserdir. Kelam âlimleri Allah Teâlẩnın kullarına karşı muhabbetini onlardan hoşnut olması ve rızası, kulların Allah Teâlâya karşı muhabbetlerini de O’na boyun eğmeleri olarak tevil etmektedirler. Tasavvuf ehli ise eserde ortaya konulduğuna göre muhabbet sıfatının hem Allah Teâlâ hem de kullar için geçerli olduğunu düşünmekte ve Allah ile kul arasındaki muhabbeti hayatın merkezine yerleştirmektedirler.

Makale inceleme ve tahkik kısmı olmak üzere iki bölümden oluşmaktadır. İnceleme bölümünde Arap edebiyatında muhabbet konusunu bağımsız olarak veya bölümler içerisinde ele alan literatüre kısaca temas edilmiş, farklı düşünce ekollerinin Allah ile kul arasındaki muhabbetin mahiyetine dair yaklaşımları genel olarak tanıtılmıştır. Ardından eserin yazarı Abdülahad Nûrînin biyografisi verilip eserleri kısaca tanıtılmış ve elyazması olanların bazı nüshalarının künyeleri verilmiştir. Tahkik edilen risâlenin içeriği özetlenmiş, metnin kaynakları belirlenmiş, içerdiği tartışmalara temas edilmiş ve yazarın görüşleri ortaya konulmuştur. Son olarak eserin tahkikinde kullanılan yazma nüshalar tanıtılmıştır.

1033/1624 yılında telif edilen eser, ilahi sevgi ve sevginin Allah ile kul arasındaki farklı boyutlarını konu almakta ve kısa bir mukaddime ile üç bölümden oluşmaktadır. Birinci bölümde kulun Allah’a karşı sevgisi, ikinci bölümde Allah’n kullarına karşı sevgisi ile ilgili görüşlere yer verilmekte, üçüncü bölümde tasavvuf ehline göre muhabbetin türleri tanıtılmaktadır. Eserde edebiyat ve tasavvuf literatüründe muhabbetle ilgili temel tanım, taksim ve nakiller derlenmiş; kelamcıların Allah’ın kula karşı sevgisi ve kulun Allah’a
\end{abstract}

* Dr. Öğr. Üyesi, Marmara Üniversitesi İlahiyat Fakültesi Arap Dili ve Belagatı Anabilim Dalı. ali.benli@marmara.edu.tr ORCID: 0000-0003-3257-8969 
duyduğu sevginin mahiyeti hakkındaki görüşlerine cevap vermek amaçlanmıştır. Müellife göre Allah’a yakınlaştıran yolların aslı Allah ve peygamber sevgisidir. Âşıklar, âbidlerin ibadet ve riyazetle uzun zamanda ulaşamadıkları mertebelere aşk ve muhabbetin cezbesiyle bir anda ulaşabilirler. Kelam âlimleri kulun sevgisinin ancak mümkün varlıklarla ilgili olabileceğini, insanların bununla tat almak veya bir zararı ortadan kaldırmak gibi bir amaç beslediklerini söyleyerek kulların Allah’a karşı sevgilerini onun rızasını istemeleri olarak tevil etmektedirler. Müellife göre ise kulun Allah’ sevmesi ondan başka bir lezzet beklemesi sebebiyle değil onun kemaline duyulan tabii meyil sebebiyledir. Allah’n kulları sevmesiyle ilgili olarak da mütekellimler muhabbetin bir meyilden ibaret olduğunu ve bunun cismani tabiata ait bir özellik olup sevginin Cenâb-1 Hak hakkında kullanıldığı âyet ve hadislerde kullarına karşı rızası anlamına geldiğini söylemişlerdir. Buna karşlık müellife göre ehl-i tasavvuf nezdinde muhabbet Allah’ın Vedûd isminin gerektirdiği ezelî bir sırdır. Bu sırrın keyfiyeti tam olarak bilinemez. Allah Teâlânın velilerine olan muhabbeti bütün varlı̆̆ın sebebidir. Bizim ona karşı muhabbetimiz aslında onun bize karşı muhabbetinin bir katresidir. Onun zatını bilmeleri için mahlukat zuhura gelmiş, onun zatının vahdaniyetine dair marifetleri onun zatını sevmelerini gerektirmiştir.

Müellif eserinde kulun Allaha duyduğu muhabbetin çeşitlerine dair ayrıntılı bir tasnif sunmuştur. Öncelikle muhabbeti failine göre avamın, havâssın ve ehassu'l-havâssın muhabbeti olmak üzere üç kısma ayırmıştır. Avâmın muhabbeti dünya (dünyevî) veya yani ahiret (uhrevî) saadetine ulaşma amacına matuf olabilir. Havâssın muhabbeti kaynağına göre sonradan kazanılmış (kesbî) veya ilahî bir ihsan (vehbî) olabilir. Muhabbetin en yüksek seviyesi karşılıksız ve tabiî olan ehassu'l-havâssa ait olanıdır.

Eserde her başlık altında âyet ve hadisler delil olarak kullanılmış, tefsir kaynaklarından yararlanılmış, özellikle tasavvuf ehlinin görüşlerini verirken Hallâc-1 Mansûr (ö. 309/922) ve İbnü’l-Fârız (ö. 632/1235) gibi şairlerin beyitlerine geniş ölçüde yer verilmiştir. Biri yazarın kendisine ait olmak üzere bu kısa risalede 63 beyit zikredilmiştir. Kelam âlimlerinin görüşleri verilirken genelde tefsir kaynaklarına müracaat edilmiştir. Müellifin eserinde sade, akıcı ve anlaşılır bir üslup sergilediği görülmektedir. Bütün bu sayılan özellikleriyle eser Allah ile kul arasındaki sevgi konusunda tasavvuf ehlinin görüşlerini derleyerek bu konudaki itirazlara cevaplar sunan derli toplu bir çalışma niteliğindedir.

Eserin tahkikinde üç yazma nüsha kullanılmış, eserde müellif tarafından yapılan alıntıların kaynakları elden geldiğince tespit edilmiş, yazma nüshalardaki kenar notlarından bazıları yazılarak eserin daha iyi anlaşılması amaçlanmıştır. Çalışmada ayrıca müellifin nüshası tespit edilememiş olan el-Erbeîniyyât fi'l-âyât ve'l-ehâdîs ve'l-hikâyât ve Şerhu kelimâti Kümeyl b. Ziyâd adlı eserlerinin nüshalarına da ilk kez işaret edilmiştir.

Anahtar Kelimeler: Abdülahad Nûrî, ilahi sevgi, Sivâsîler, Kadızaleliler, Osmanlı tasavvuf geleneği

Abstract: This study consists of a critical edition and analysis of Hujjat al-widād wa
hijjat al-fu'äd, a treatise on divine love, by Abdulahad Nürī (d. 1061/1651), a $17^{\text {th }}$ cen-
tury Ottoman Sufi scholar. Nürī is of Sivas origin and belongs to a family (the Sivasis)
famous for their Sufi upbringing and background are widely known among Sufi schol-
ars. Much of Nūrîss scholarly work consists of the rejoinders he wrote to the Kadizadelis
of his time who were overly critical of the Sufi tradition. Among the disputes of this pe-
riod concerning this subject, the following specific topics can be noted: whether or not
the parents of the Prophet attained faith and became Muslims, whether or not the Sufi
whirling (dawrän) is permissible, the benefits of dhikr, the question of tayy-i makān, the 
transmission of the requital of good deeds to deceased beloved ones, and the act and manners of the awliy $\vec{a}^{\prime}$ Alläh (saints). The treatise Hujjat al-widäd is a piece of literature on divine love and is considered a qualitative work of Sufi response to prevalent topics being discussed at the time.

This article written in Arabic is composed of two parts, first, there is an analysis of the treatise, and secondly, there is a critical edition. The first part lists and summarizes the works carried out on divine love (mahabba), the relation between God and the servant through this divine love, and the nature of this love. Thereafter, a short biography of Abdulahad Nūrì is offered, his works are introduced, and some names of extant manuscript copies of his works are listed. The content of the treatise under study is summarized, its resources identified, the main points of arguments are ascertained and the author's primary thesis is presented. Finally, the manuscript copies that were used for the critical edition are introduced and discussed.

The treatise was composed in the year 1033/1624 and deals with different dimensions of divine love and affection between God and His servants and consists of three chapters and a short introduction. The first chapter addresses the love of the servant for God, whereas the second chapter investigates God's love for his servants, and the third chapter introduces the types of love (mahabba) there is according to the Sufi tradition. The treatise includes a compilation of the standard definition, division, and narratives about mahabba prevalent in the Sufi literature. Moreover, it also aims to address and answer the view of the Mutakallimūn on God's love for His servants and the quiddity (mähiyya) of the servant's love for God. According to Nūrī, the essential way in which one can get closer to God is through the love of God and His Prophet. The lovers (äshiqūn) can attain and be elevated to degrees instantaneously, which the worshippers ('äbidün) who carry out ritualistic worship cannot reach even within a long period of time. According to the mutakallimūn, the object of the love of the servant can only be possible existence, because human love can be used for the purpose of gaining pleasure or to eliminate harm. Accordingly, they interpret (ta'wil) the love of the servant for God as the goal to attain God's goodly pleasure ( $\left.r i d \bar{a}^{\prime}\right)$. Nūrì, on the other hand, thinks that the reason the servant loves God is not because he expects to gain other pleasure from Him but because he inherently has a natural inclination ( mayl) towards attaining the most ultimate and perfect state (kamāl). As for God's love for His servants, the mutakallimūn argue that mahabba is constrained to being merely an inclination ( $m a y l$ ) and that it is a quality of a physical nature. Therefore, verses and sayings of the Prophet which mention love ought to be understood as God being pleased with His servants (rid̄à). Nūrī, however, enlists the following argument of the Sufi scholars by contending that Mahabba is an eternal secret (al-sirr al-azalī) in accordance with and entailed by God's name Wadūd, which is one of His 99 names. Therefore, it is not possible to grasp the quality of this secret. Furthermore, God's love for his near servants (awliy $\vec{a})$ is the cause of all existence. Our love for Him with respect to His love for us is only of an infinitesimal measure by comparison. All humankind has come to appear (zuhür) to know of His existence (dhāt) and their knowledge of the oneness of His essence (dhāt) has caused them to have a love for Him.

Under each subchapter, the treatise contains verses and sayings of the Prophet used as evidence for the argument, and extended passages are included from principal Qurānic exegeses, in particular, verses by Manșūr al-Ḥallāj (d. 309/922) and Ibn alFāriḍ (d. 632/1235) that have been quoted among the passages mentioning the views of the Sufi scholars. In total, 63 verses appear in the treatise with one of them belonging to Nürī himself. The author exhibits a plain, fluent, and clear writing style throughout the 
treatise. Hujjat al-widād wa hijjat al-fu'äd is a concise and collective work in which the views of the Sufi scholars on the love relation between God and His servants are compiled, and responses to the criticism of these views by other schools are also included.

Three copies have been used in this critical edition of the treatise, the sources of the quotes made by the author have been identified, and the side notes (häshiya, ta'līqät) on the manuscripts have also been transcribed.

Keywords: Abdulaḥad Nūrī, divine love, Sivāsīs, Kādīzādelīs, Ottoman Sufi tradition 


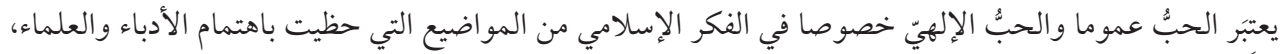

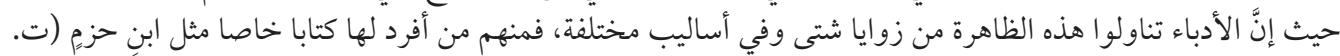

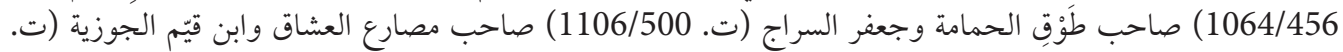

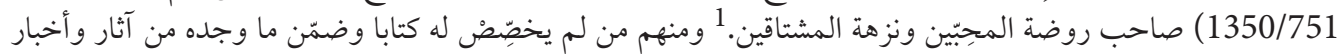

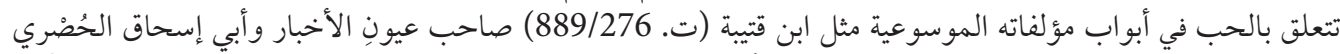

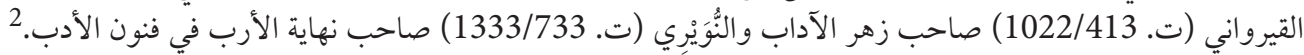
أما العلماء فتناولوا ظاهرة الحب من حيث تعلقها بذات الله تعالى وصفاته واختلفوا في فهمها وتفسيرها، الجهم بن

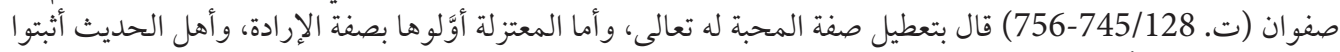

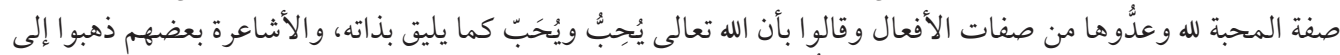

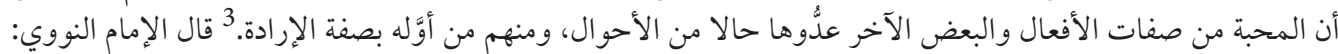

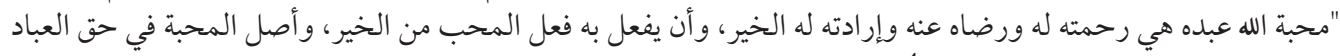

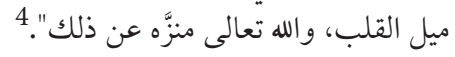

يعَدّ الحب عند الصوفية ببعدَيْهِ الإنساني والإلهي مفهوما جوهريا يمتد جذوره من منابع الإسلام الأصيلة، فمحبة الله

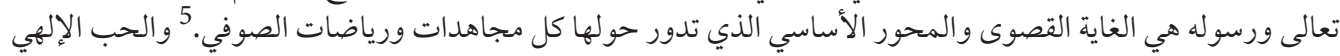

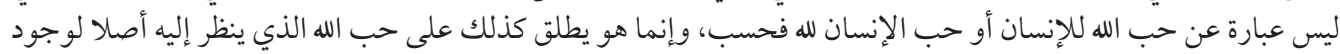
الخلق وواسطة في سريان الحياة والحركة في الكون.6 يشير الشيخ الأكبر ابن عربي (ت.

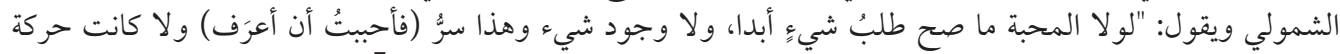

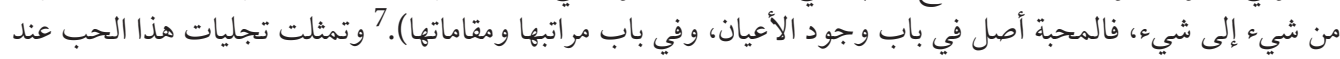

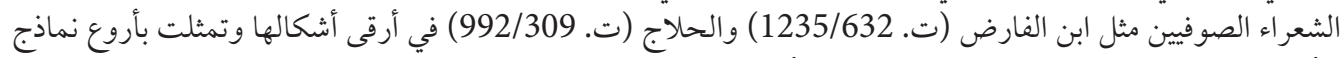

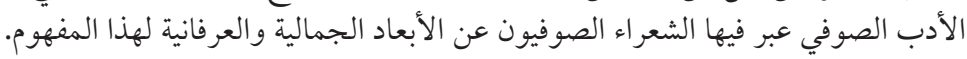
وكان الشيخ عبد الأحد النوري السيواسي الذي يعتبر من أعلام التصوف في العهد العثماني ألف في هذا المجال رسالة

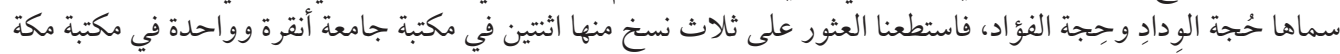

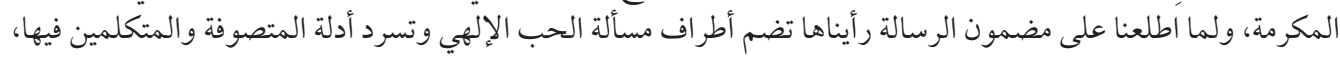

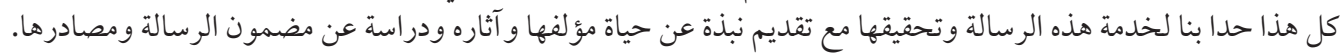

\section{1. الدراسة}

\section{1. ترجمة موجزة للمؤلف}

الشيخ الفاضل أبو المكارم أوحد الدين عبد الأحد النوري بن مصطفى مصلح الدين صفايي بن إسماعيل بن محمد 1 مداد

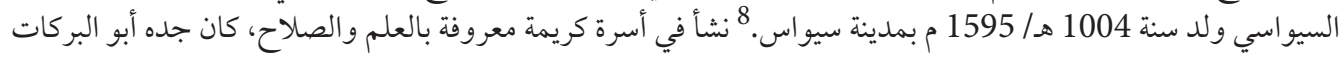

$$
\begin{aligned}
& 1 \\
& \text { 2 } \\
& 3 \\
& \text { 4 } 4 \\
& \text { 5 } 5 \\
& 6 \\
& \text { } 7 \\
& 8
\end{aligned}
$$

[Osman Türer, Muhammed Nazmi ve Hediyyetül-İhvân’, s. 213-5.] 


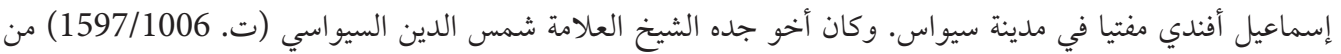

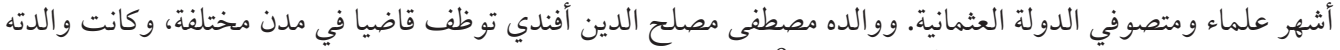

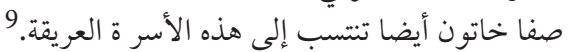

توفي والده القاضي مصطفى مصلح الدين أفندي وهو صغير جدا، فتولى خاله الشيخ عبد المجيد السيواسي تربيته،

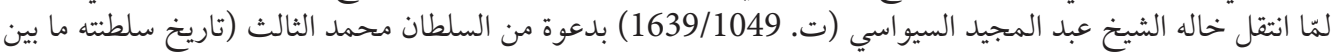

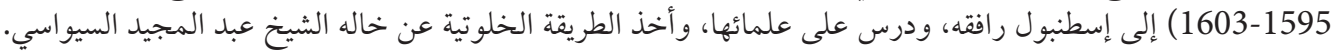

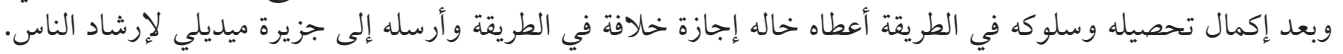

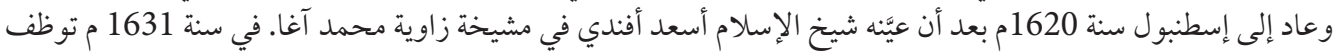

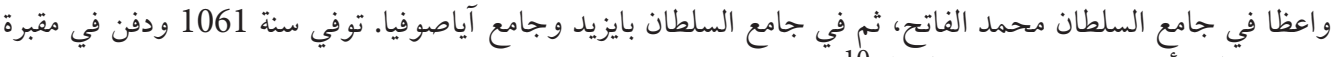
شيخه بمطنقة أيوب نيشانجه في إسطنبول. 10

1.2

ألف الشيخ عبد الأحد النوري في العلوم الإسلامية والتصوف والوعظ عدة كتب ورسائل باللغتين العربية والتركية، 11

1. مرآة الوجود ومرقاة الشهود: تناول المؤلف فيها وحدة الوجود وبسط فيه القول بإيراد الأدلة والأجوبة في سبعة

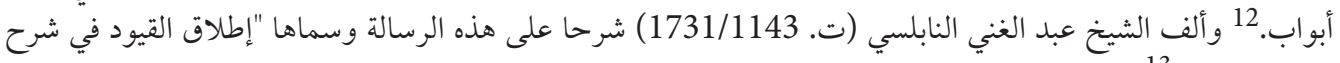
مرقاة الوجود".

2. رياض الأذكار وحياض الأسرار: تشتمل هذه الرسالة على آراء أهل التصوف في الذكر وأصوله وأنو اعه وفضائله،

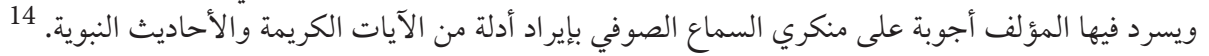
3. حكمة التعارض في صورة التناقض. 15 تناول المؤلف في هذه الرسالة مسائل مشكل القر آن ويحاول التوفيق بين ما يفهم منه التعارض من الآيات الكريمة.

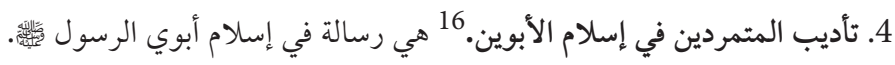
5. رسالة في طي المكان. حاول المؤلف في هذه الرسالة إثبات كرامة "طي المكان" للأولياء. 17 وقائع الفضلاء لشيخي ، 1 / / 547 ؛ سفينة أولياء أبرار شرح أسمار أسرار لحسين وصاف، مكتبة سليمانية، قسم يازمه باغيشلار ، رقم 2307، ص 357. Mehmed Tahir, Osmanl Mü̈ellifleri, s. 51-52.

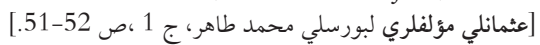
İbrahim Baz, Abdülehad Nûrî Sivầsî Hayatı Eserleri Görǚşleri, s. 69.

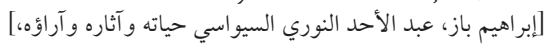
إبراهيم باز ، المصدر السابق، Uçman, “Abdülehad Nûrî", s. 178-9.

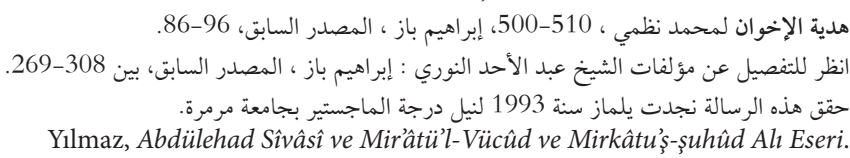
حقق هذا الشرح ونشر سنة 2017. عبد الغني النابلسي ، إطلاق القيود شرح مرآة الوجود ومرقاة الشهود، (تحقيق: د. عاصم الكيالي)، مكتبة قوت

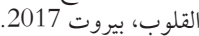
14 15 Bal, Abdulahad Nurî Sivasînin Hikmetu't̂-Teâruz Fî Surati't-Tenâkuz Adlı Eseri.

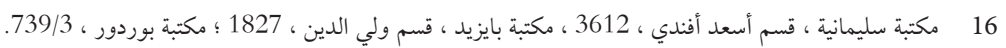

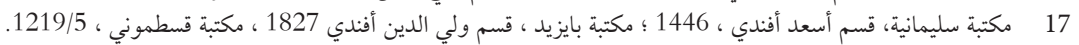




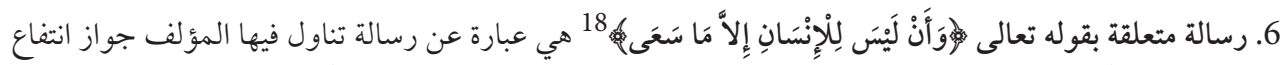

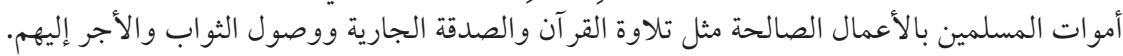

7. إثبات العلم والشعور لمن كان من أهل القبور: تناول المؤلف في هذه الرسالة جواز زيارة القبور. 19 8. إنقاذ الطالبين عن مهاوي الغافلين. 20ُكُّفت هذه الرسالة القصيرة للدعوة إلى إخلاص النية في طلب العلم.

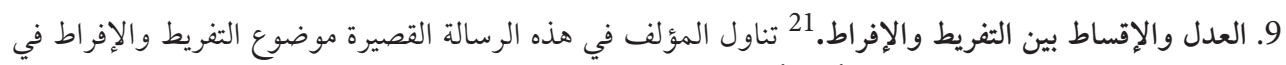

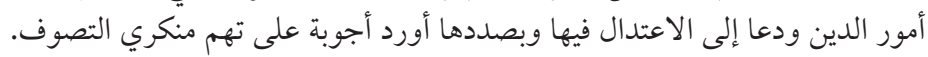

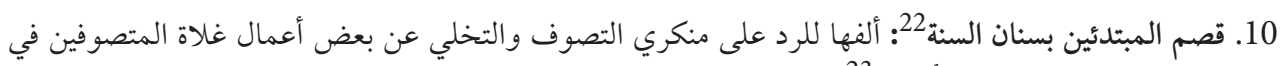
عهده، وحاول فيها إثبات كرامات الأولياء. 23

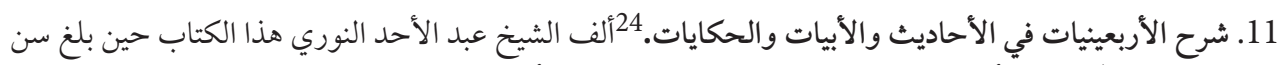

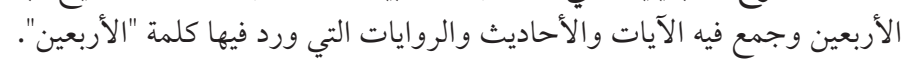
12. شرح كلمات كميل بن زياد. 25 شرح المؤلف في هذه الرسالة أجوبة علي بن أبي طالب -ض - لأسئلة وجهها إليه كميل بن زياد. 13. مراتب معرفة الرحمن. 26 شرح المؤلف فيها آراء العلماء والمتصوفين في مراتب معرفة الله تعالى.

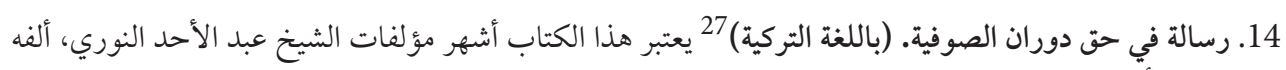
في الرد على من أنكر السماع الصوفي وحرمها. 15. ترجمة تأديب المتمردين. (باللغة التركية)28 هي ترجمة لرسالته العربية التي ألفها للرد على من أنكر إسلام أبوي الرسول

16. سلسلة نامة. هي منظومة باللغة التركية يذكر فيها الناظم سلسلته في الطريقة.29 17. ديوانه باللغة التركية.

\footnotetext{
18 18

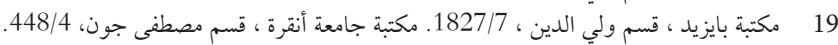
20 20 2 21

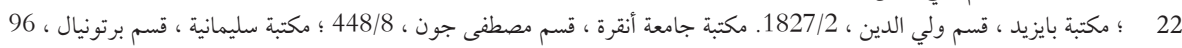
23 إبراهيم باز، المصدر السابق، ص ص 282 24 25 26

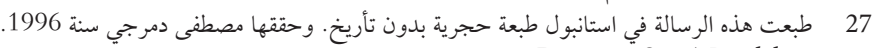
Demirci, Semâ Risaleleri. 28

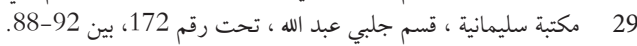
Abdülahad Nûrî Dîvânı (2001); Abdülahad Nuri ve Divanı: İnceleme ve Tenkitli Metin (2003).
} 


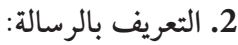

\subsection{1 عنوان الرسالة ونسبتها إلى المؤلف وتأريخ تأليفها}

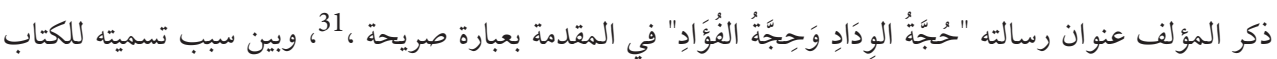

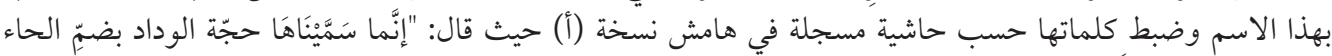

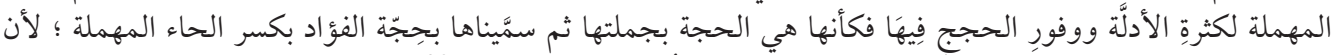

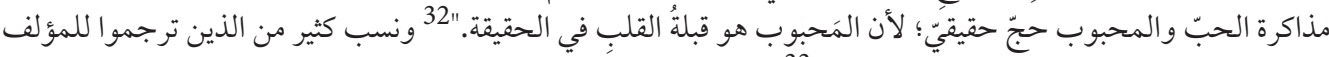

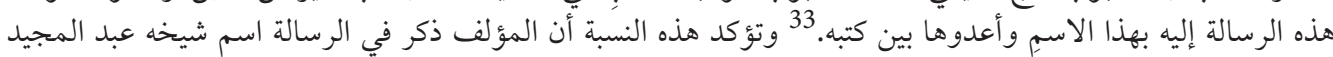

$$
\text { السيو اسي وتكلم عنه. }
$$

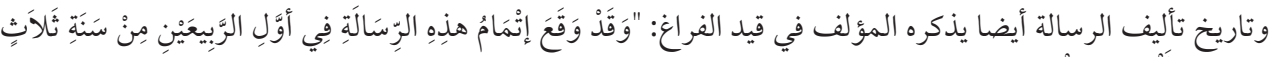

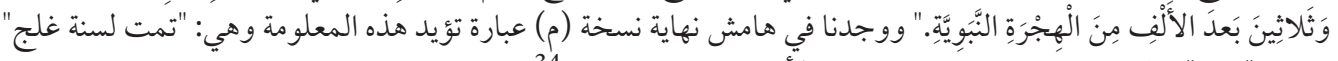

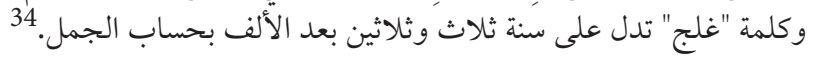

2.2. محتوى الرسالة ومصادرها

يشكل الحبُّ الإلهيُّ موضوع الرسالة ويتناوله المؤلف من وجهتين أساسيتين: وهما محبّة العبد لربه تعالى ومحبّة

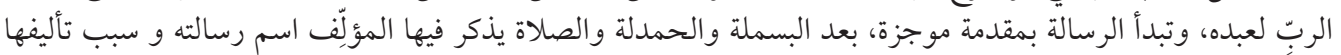

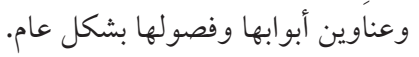

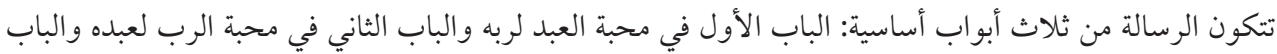

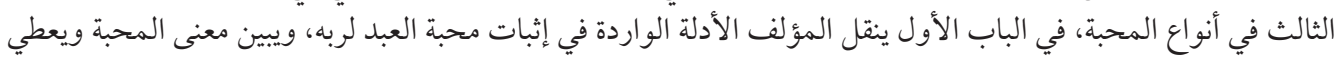

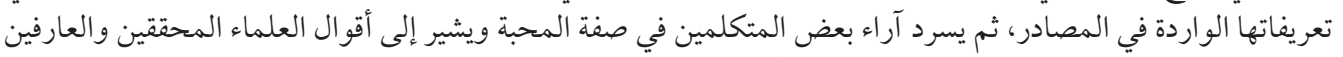

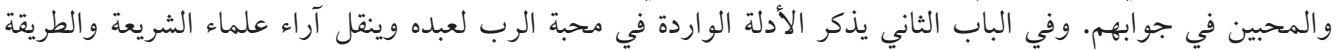

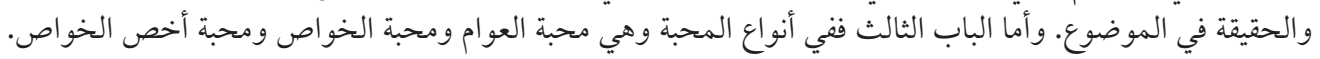

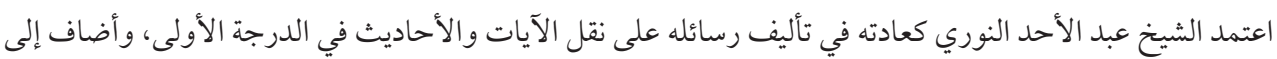

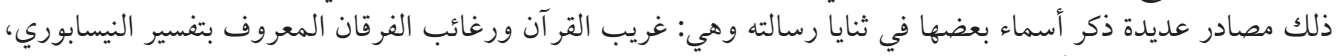

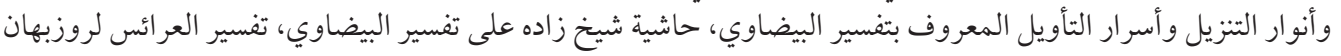
البقلي، وتفسير الرازي، الرسالة الغوثية لعبد القادر الكيلاني.

ولا نسىى أن نشير إلى أن المؤلف اعتنى بالشعر واستشهد به كلما اقتضى المقام وووصل عدد الأبيات التي نقلها في

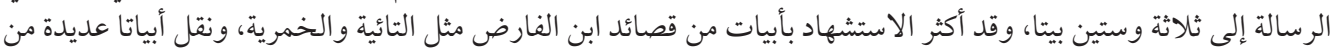

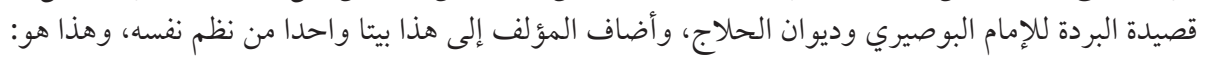

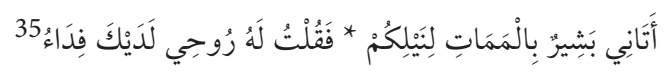

31 31

32

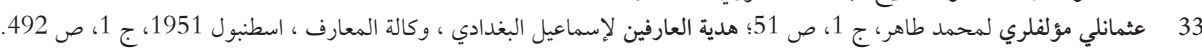

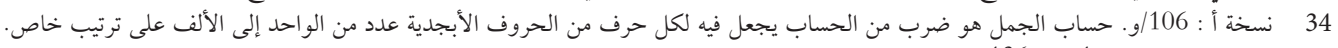


كل ذلك ينم عن اطلاع واسع على مصادر الأدب والتصوف والعلوم الإسلامية، نرى أن أسلوب المؤلف في هذه الرسالة ينسجم مع أسلوبه في مؤلفاته الأخرى، ويمتاز بحجز الة الة الألفاظ ووضوض وضوح التعبير وإحكام الصياغة.

تبرز أهمية الرسالة وقيمتها العلمية من خلال موضوعه الذي شغل العلماء والمتصوفين في عهد المؤلف، وهو فيها

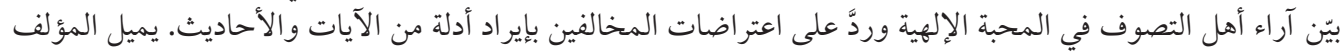

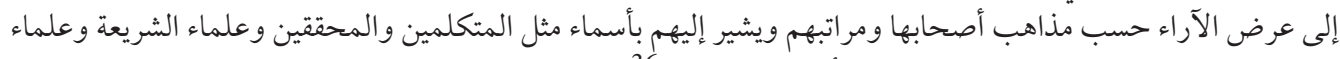

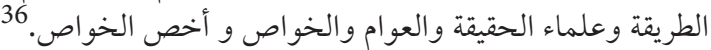

\subsection{1 المحبة بين المتكلمين والصوفية}

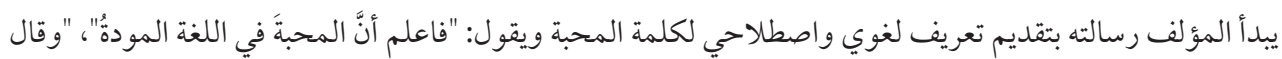

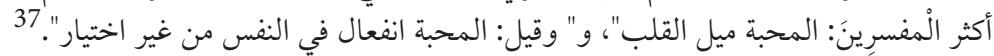
يرى المؤلف أن محبة الله تعالى ورسوله عليه السلام أصل الأصول في طريق التقرب إلى الله، وهي أفضل سبيلٍ

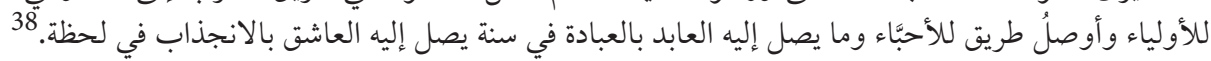
يشير الشيخ عبد الأحد السيواسي إلى أن المتكلمين ذهبوا إلى تأويل محبة العبد لله تعالى بالطاعة والخضوع ويقول:

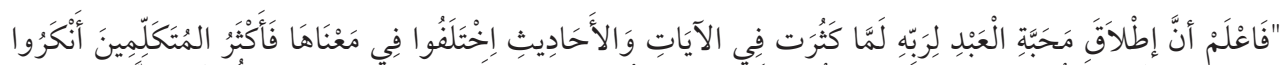

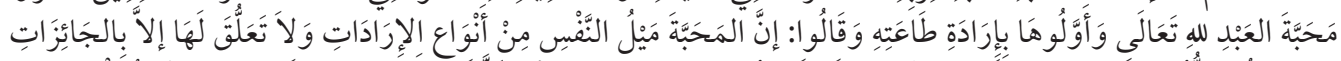

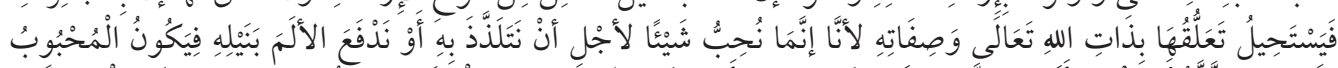

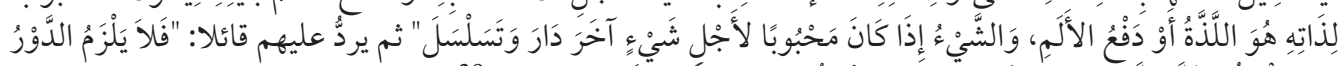

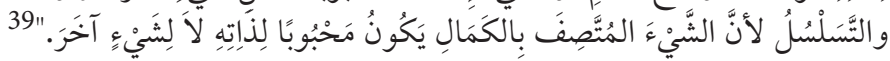

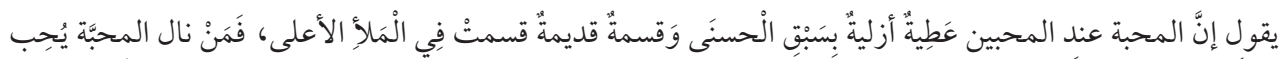

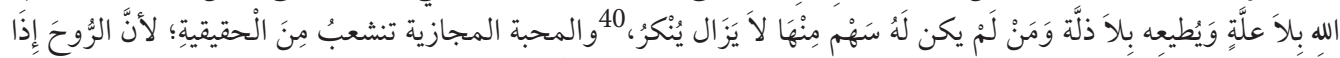

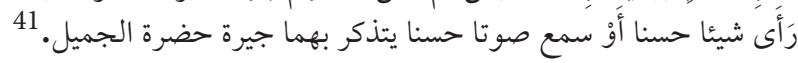

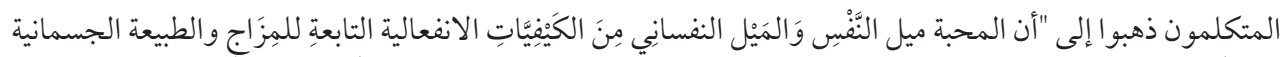

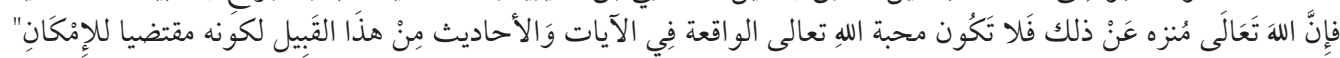

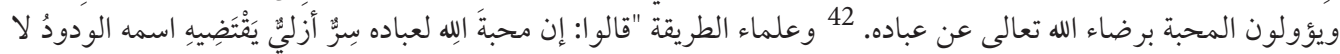

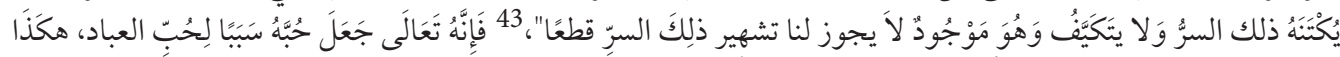

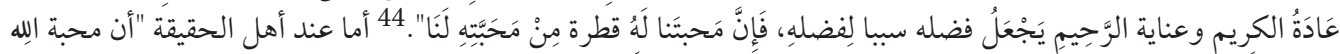

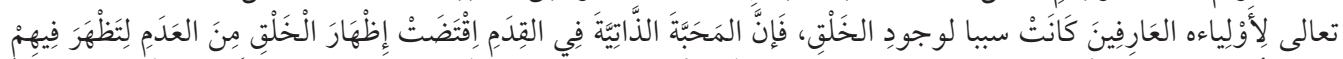

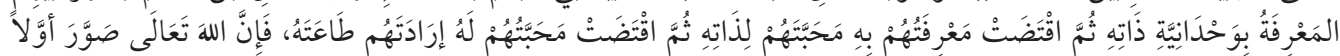

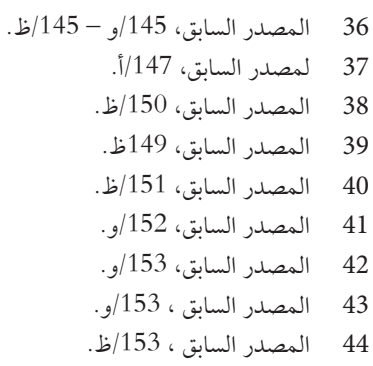




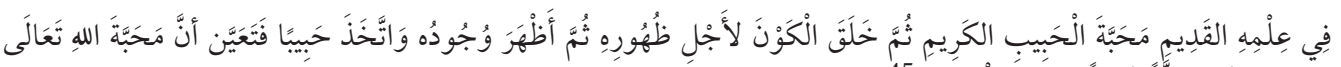

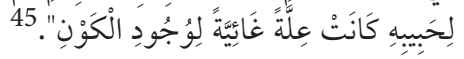

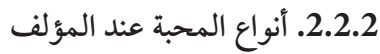

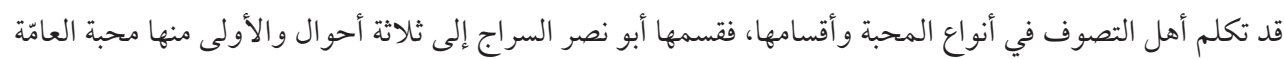

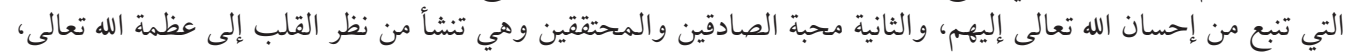

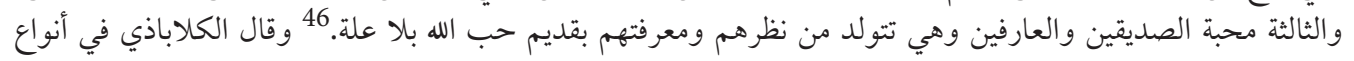

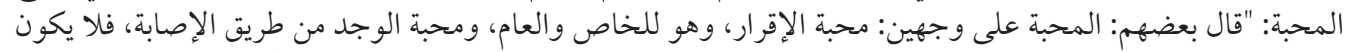

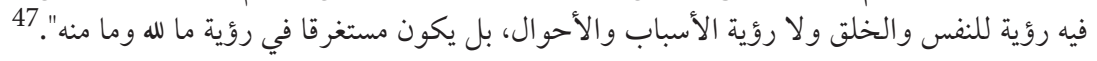

$$
\text { 1. المؤلف وضع تقسيم مفصلا لأنواع المحبة وهي عنده ثلاثة أنواع: }
$$

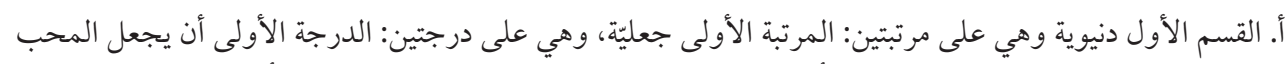

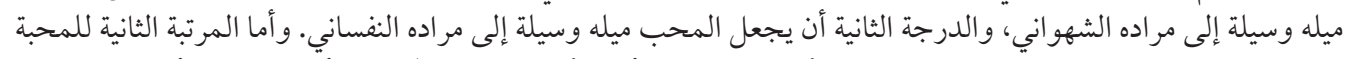

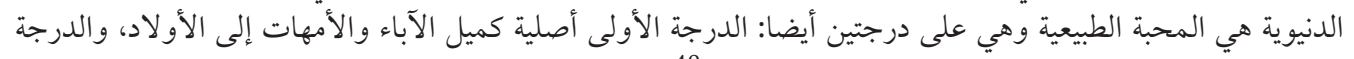
الثانية عارضية كميل الطبع إلى المحبوب بمجية بمجرد الاستماع.

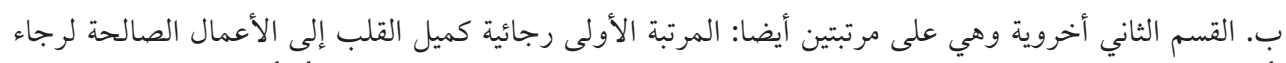

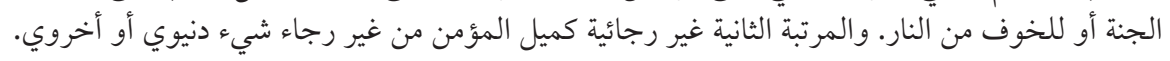

$$
\text { 2. النوع الثاني محبة الخواص وهي على قسمين أيضا: }
$$

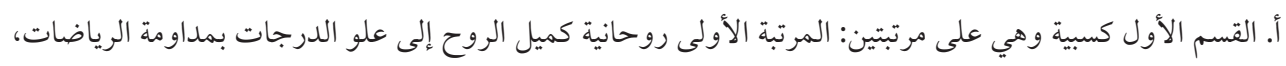

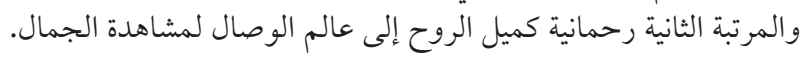

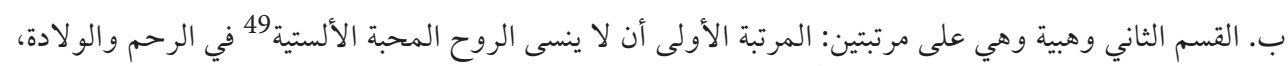

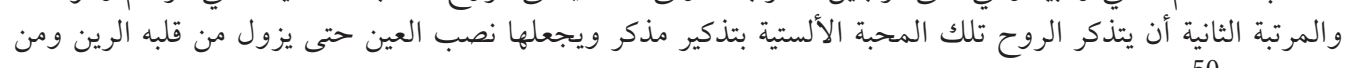
عينه الغين.50

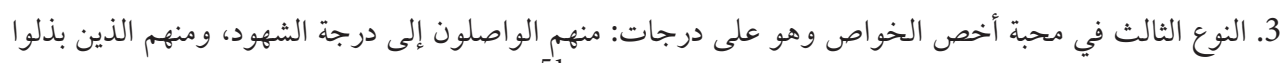

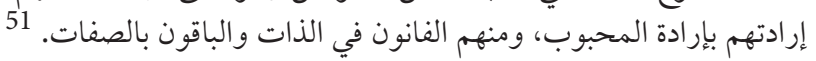




\section{3.}

$$
\text { تيسر لنا الوقوف على ثلاث نسخ خطية لهذه الرسالة وإليك وصفها: }
$$

أولا: نسخة جامعة أنقرة (قسم الجامعة)

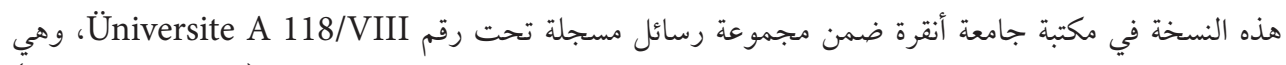

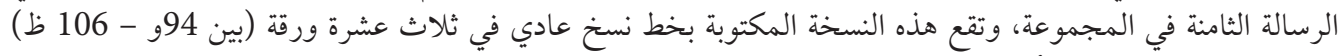

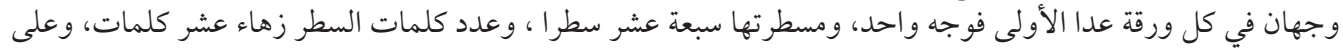

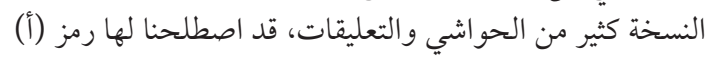

ثانيا: نسخة جامعة أنقرة قسم مصطفى جون

هذه النسخة في مكتبة جامعة أنقرة قسم مصطفى جون ضمن مجموعة رسائل مسجلة تحت رقم

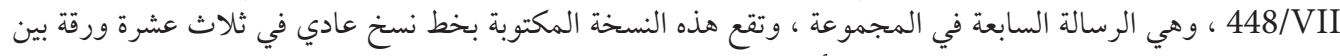

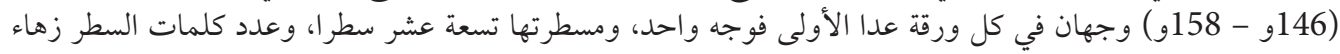

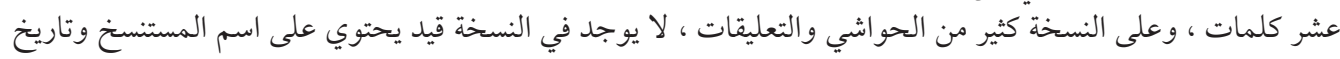
الاستنساخ، قد اصطلحنا لها رمز (م).

\section{ثالثا: نسخة مكتبة مكة المكرمة}

هذه النسخة في مكتبة مكة المكرمة قسم التصوف ضمن مجموعة رسائل مسجلة تحت رقم "تصوف 70" ، وهي الثي

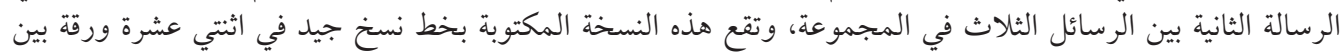

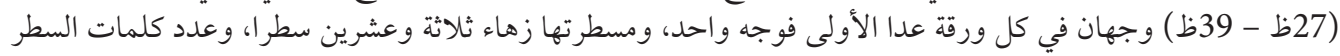

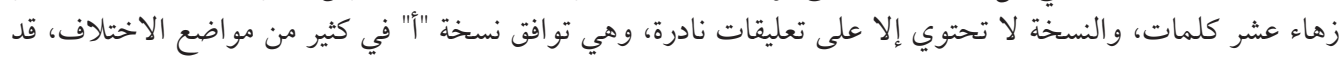

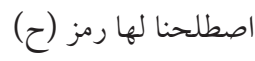

\section{4ملنا في التحقيق}

اعتمدنا على أسس وقو اعد مركز البحوث الإسلامية ISAM في التحقيق. 52 قمنا بمقابلة ثلاث نسخ خطية وصفناها

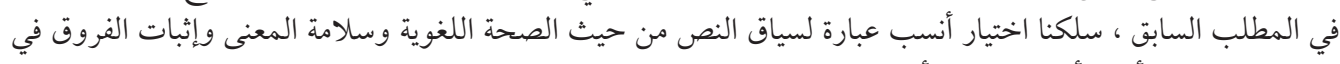

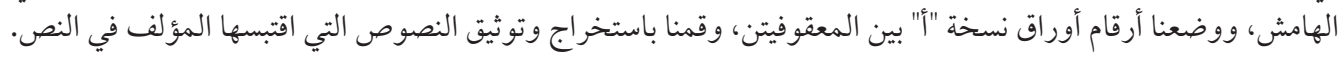



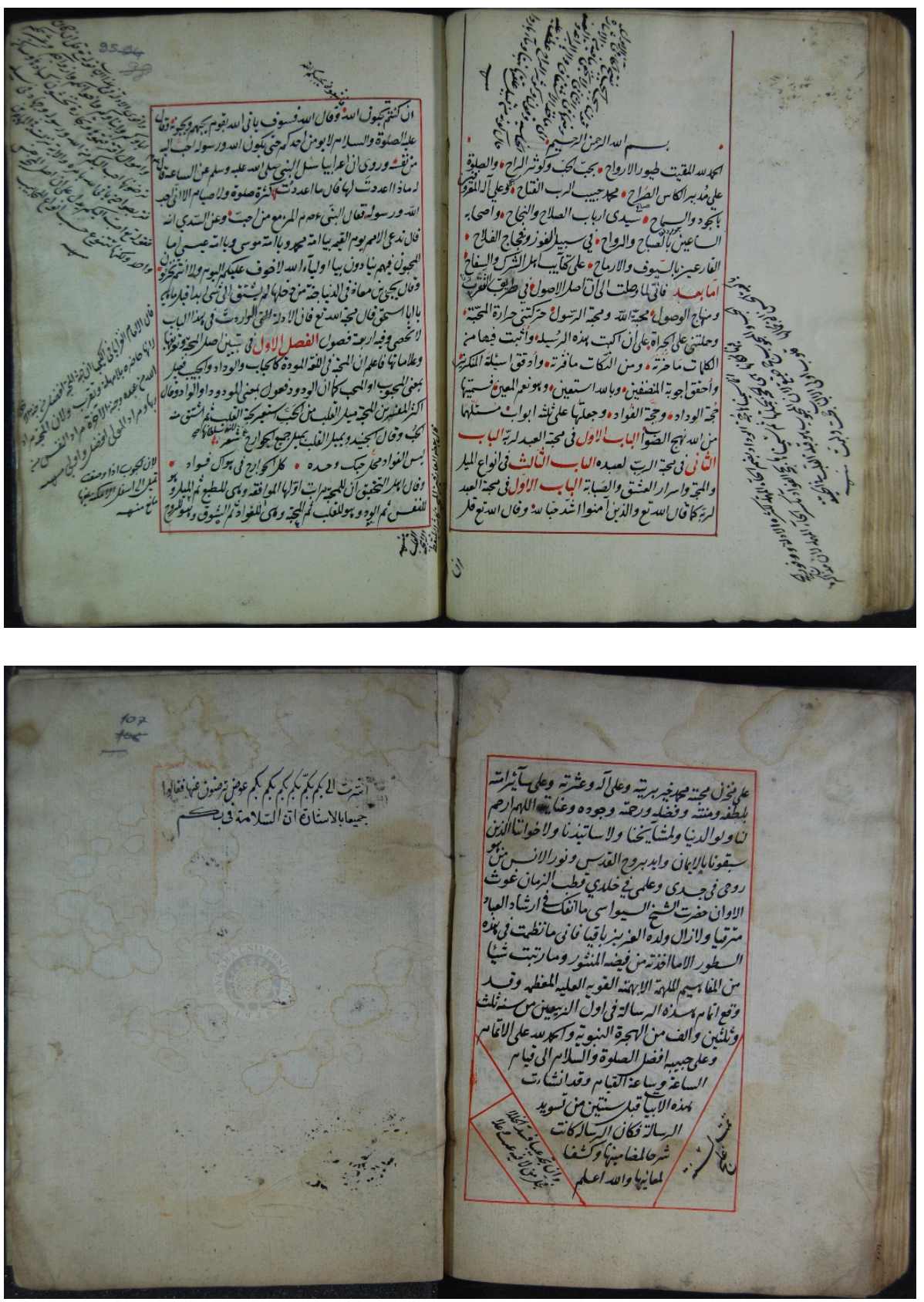

صورة اللوحتين الأولى والأخيرة من نسخة جامعة أنقرة، رقم Üniversite A 118/VIII، رمزها "أ". 

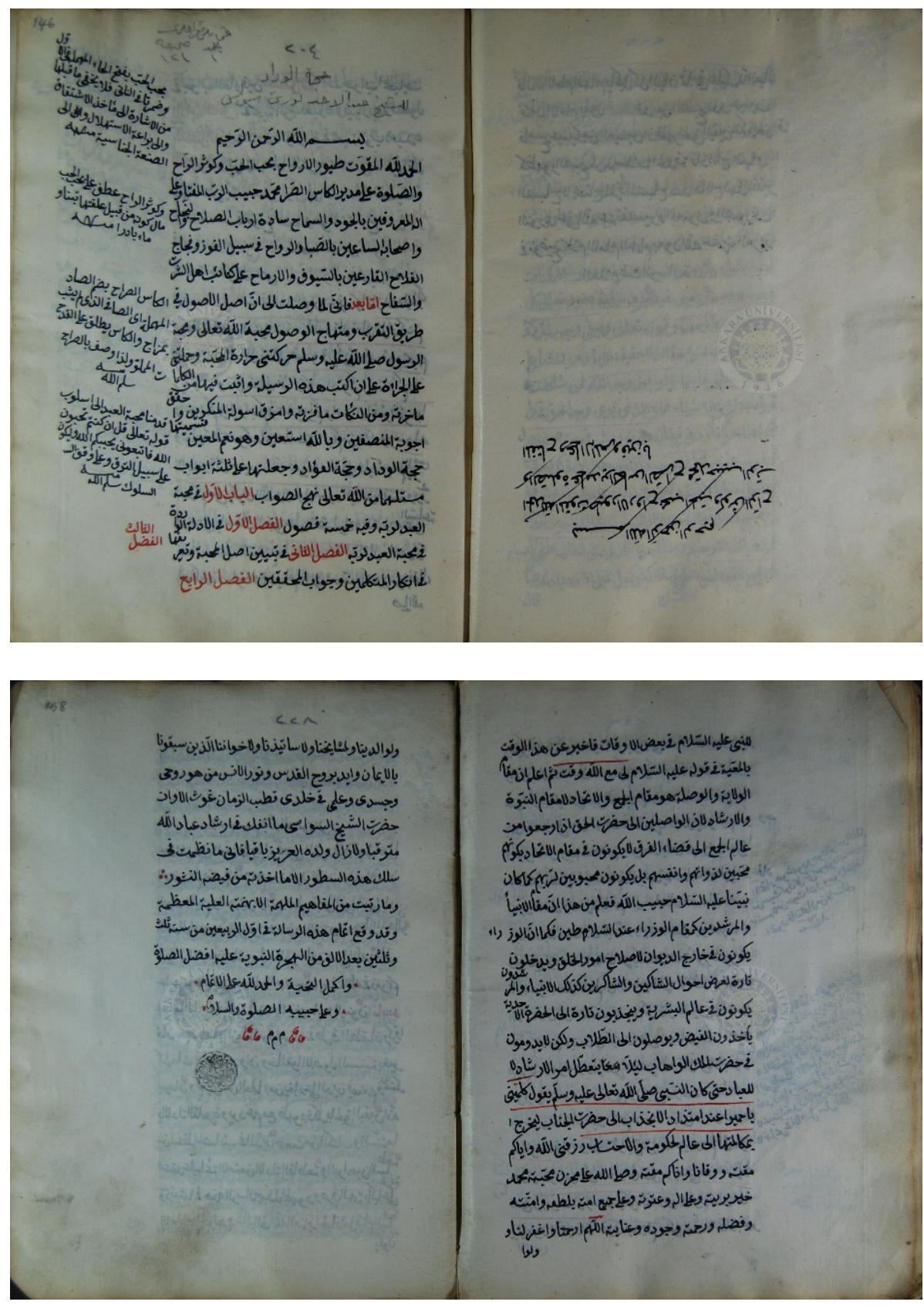

صورة اللوحتين الأولى والأخيرة من نسخة جامعة أنقرة قسم مصطفى جون، رقم Mustafa Con A 448/VII ، رمزها "م". 

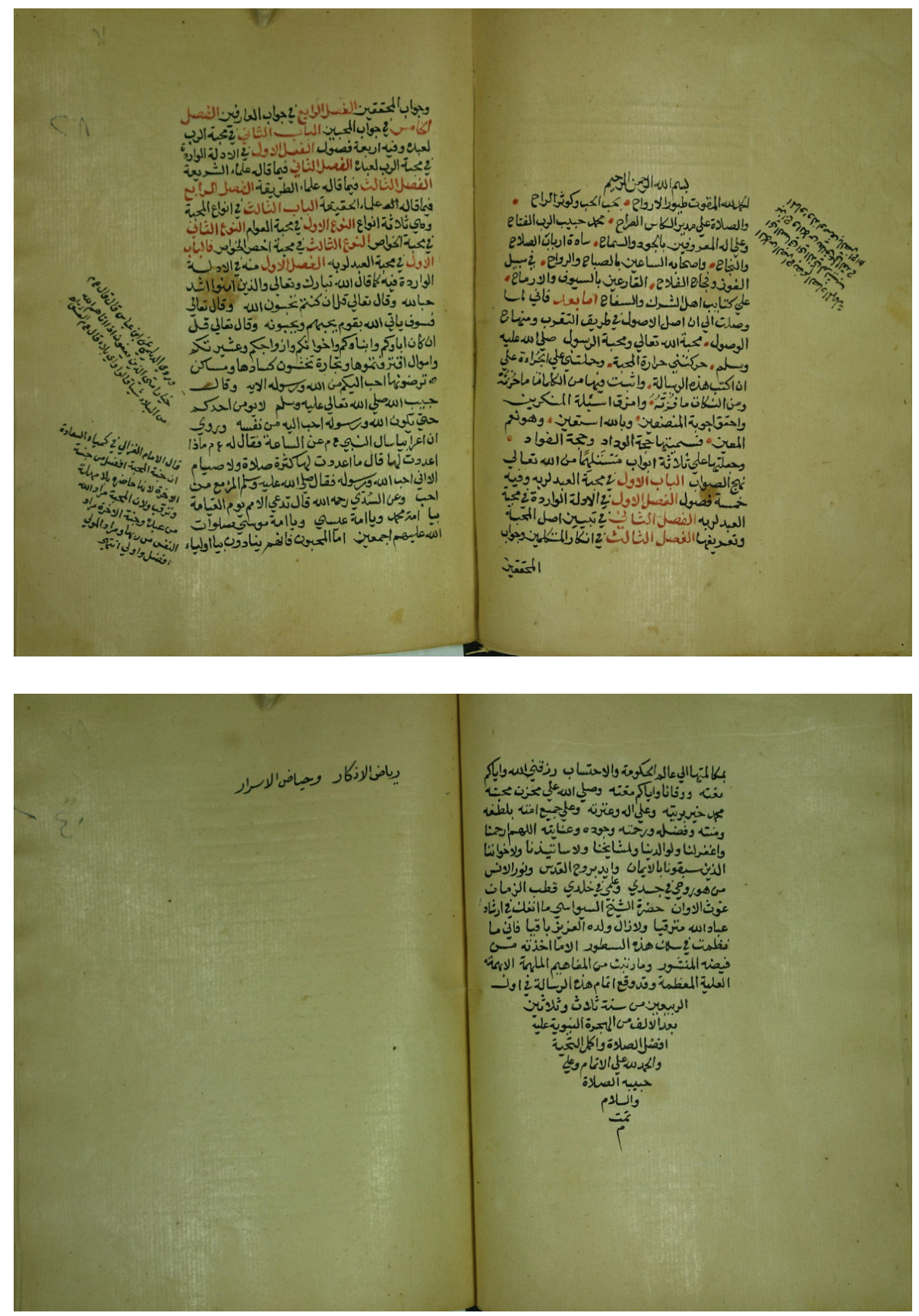

صورة اللوحتين الأولى والأخيرة من نسخة مكتبة مكة المكرمة المسجلة تحت رقم "تصوف 70" ، رمزها "ح". 


\section{حُجَّةُ الْوَدَادِ وَحِجَجة الفُوًَاد}

$$
\text { بِسْمِ اللهِ الرََّحْمِنِ الرَّحِيمِ }
$$

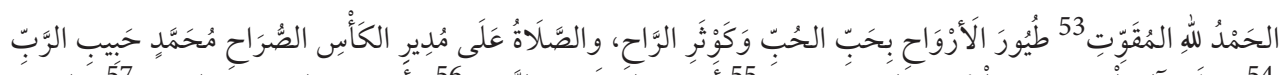

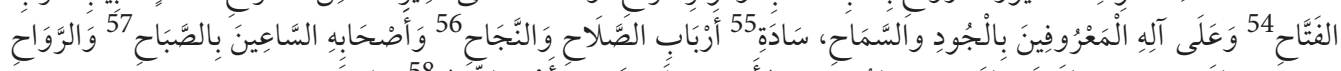

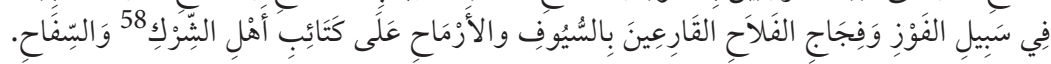

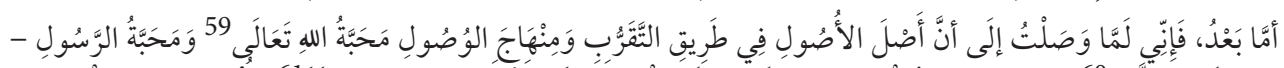

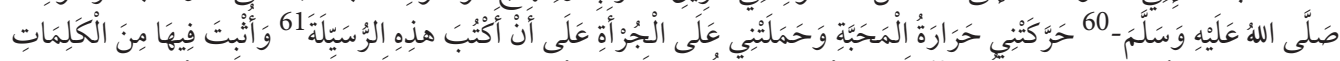

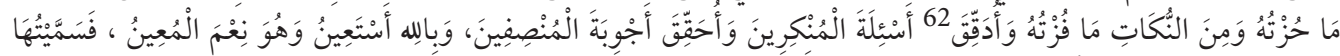

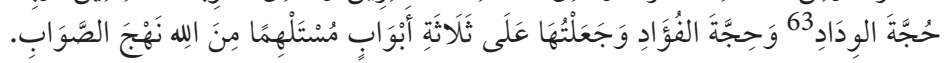

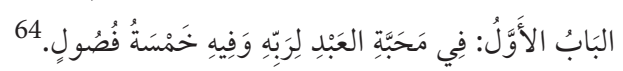

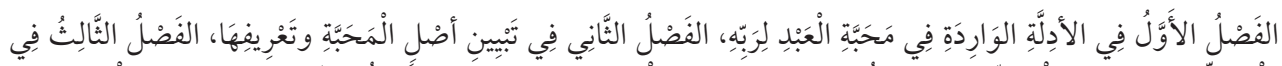

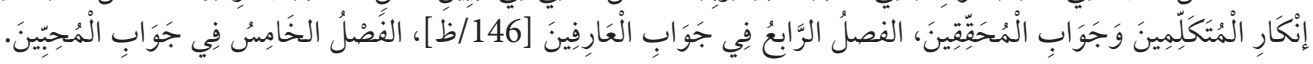

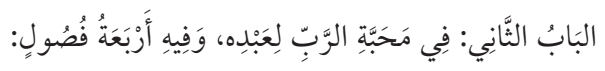

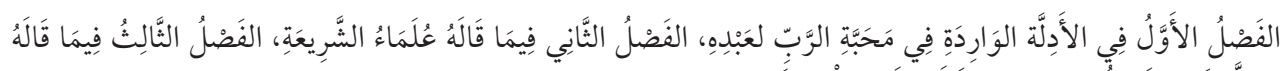

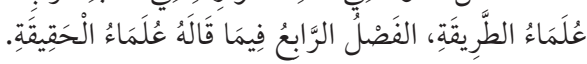

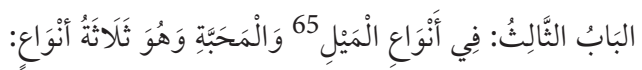

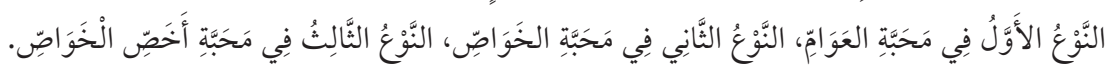

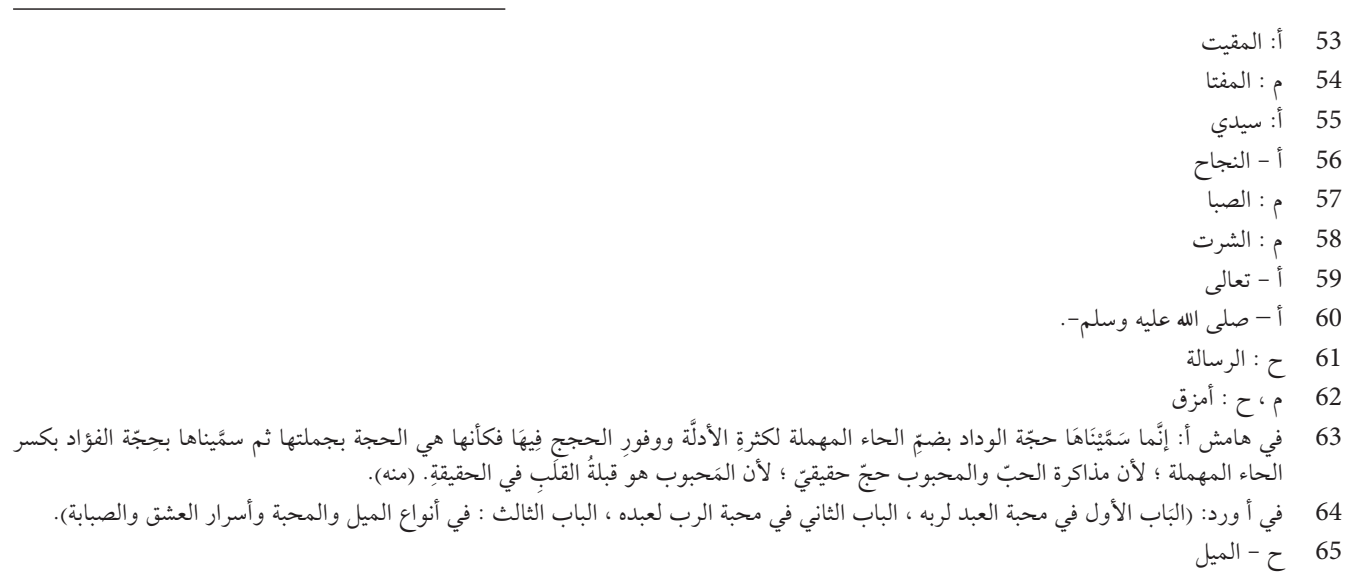




\section{البَابُ الأَوَّلُ فِي مَحَبَّةٍ العَبْدِ لِرَبَّه \\ الفَصْلُ الأَوَلْ مِنْهُ فِي الأَدِلَّة الوَارِدَةِ فِيهِ}

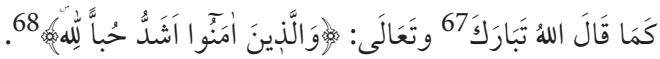

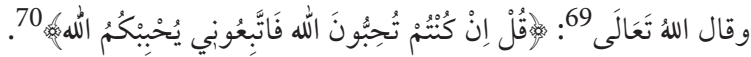

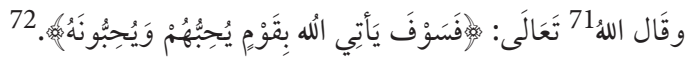

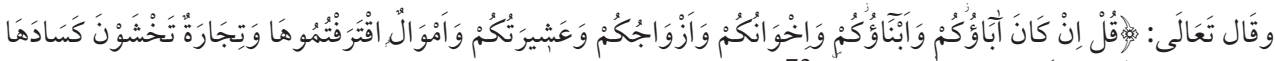

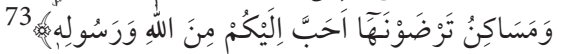

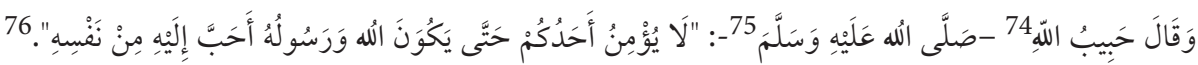

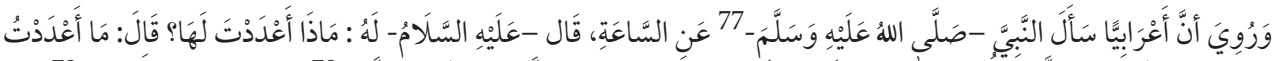

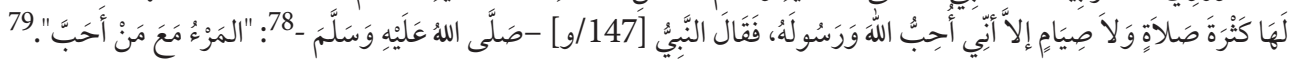

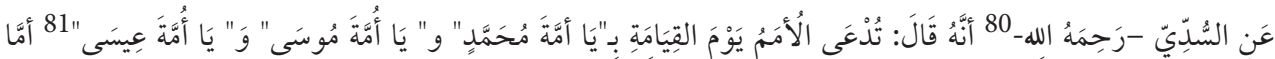

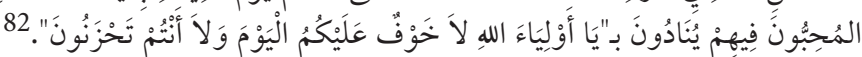

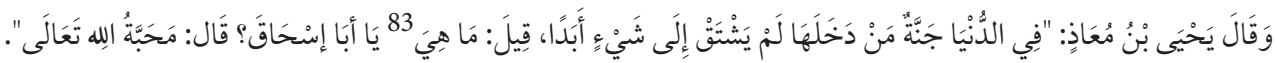

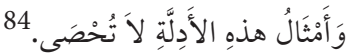

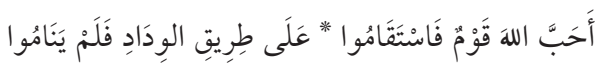

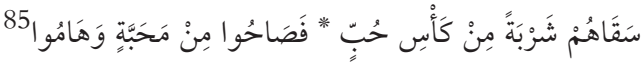

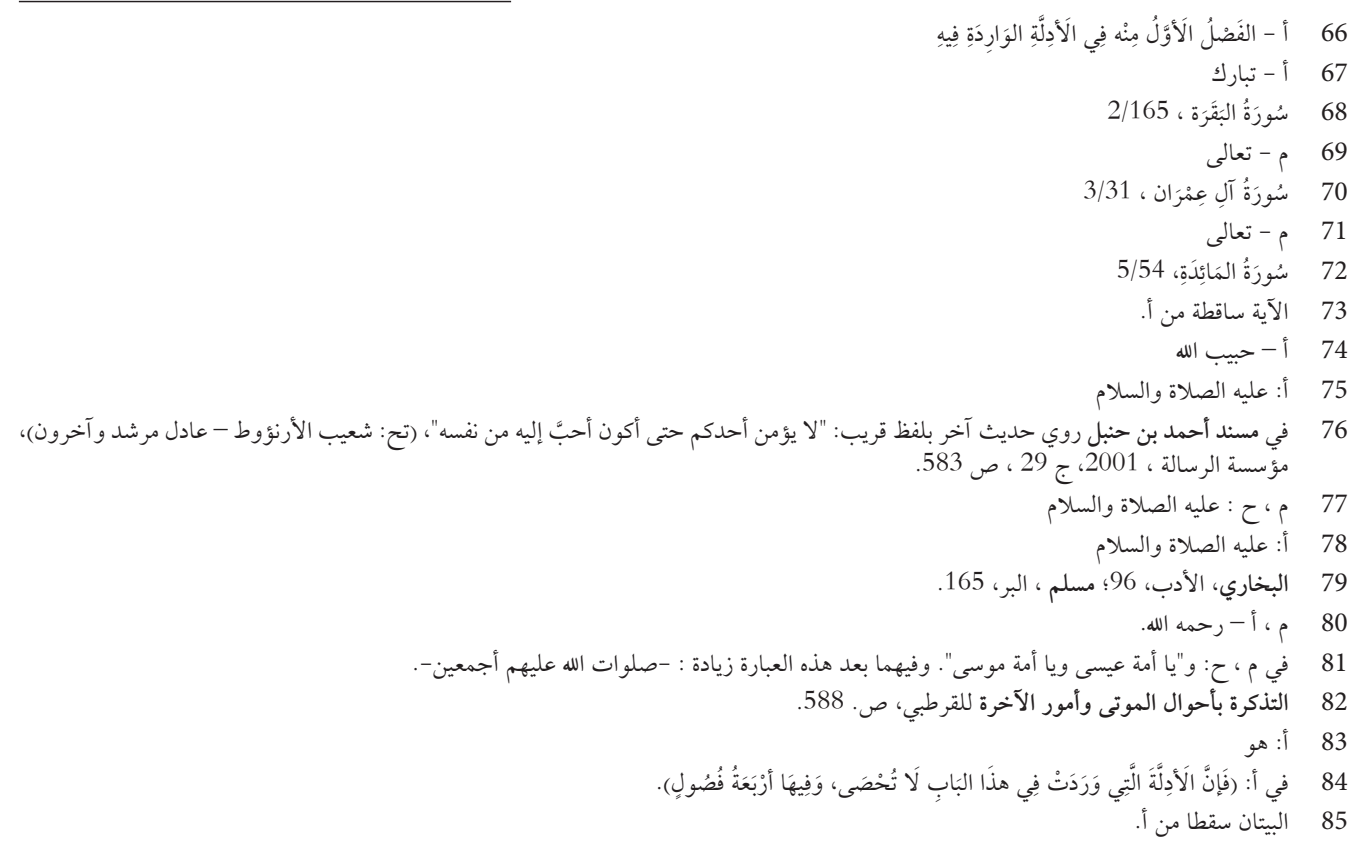




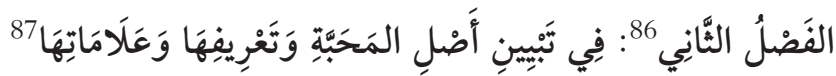

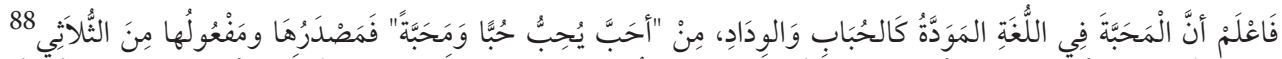

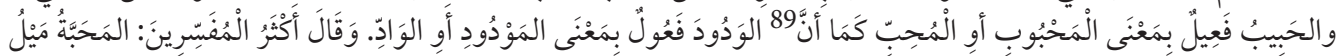

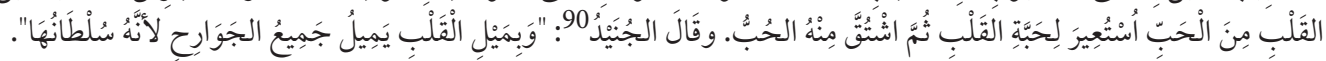

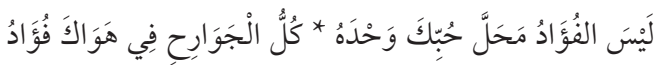

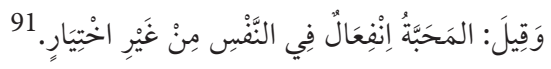

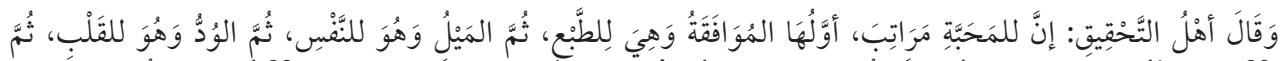

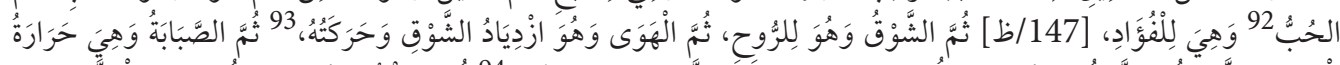

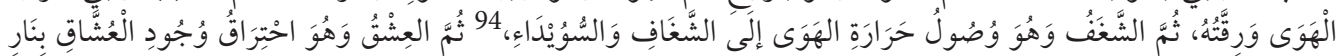

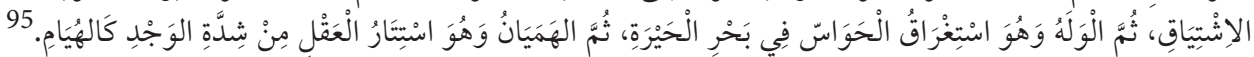

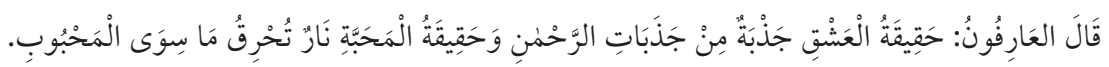

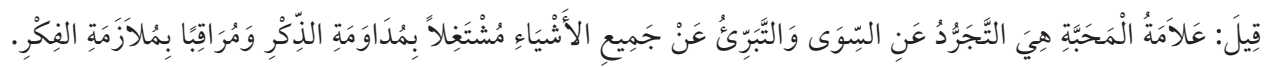

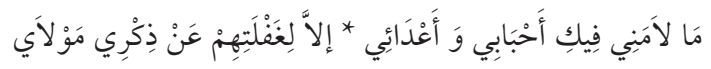

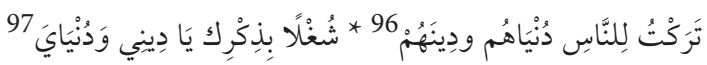

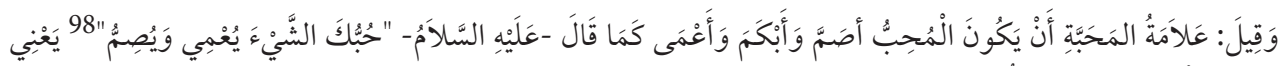

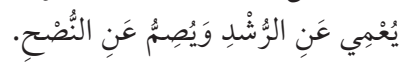

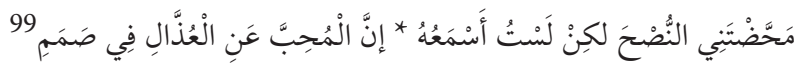

$$
\begin{aligned}
& 86 \text { 8 } 86 \\
& 87 \\
& 88 \\
& 89 \\
& 90 \\
& 91 \\
& 92 \\
& 93 \\
& 94 \\
& 9596 \text { ح ح: وكذلك الهيام، م: ثم الوله وهو استتار العقل بغلبة الوجد ثم الهيمان وهو استغراق الحواس في بحر الحيرة وكذلك الهيام. } \\
& 96 \\
& 97
\end{aligned}
$$

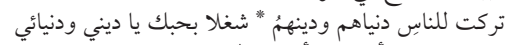

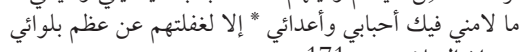

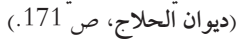

$$
\begin{aligned}
& 98 \\
& 99 \text { البيت هو البيت الثالث عشر من قصيدة البردة للإمام البوصيري ، انظر : شرح البردة للإبراهيم الباجوري، (تح: عبد الرحمن حسن محمود)، مكتبة الآداب، }
\end{aligned}
$$




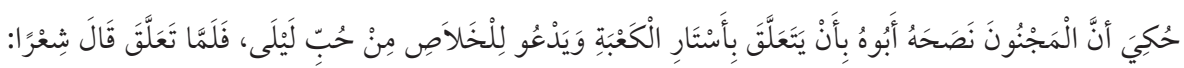

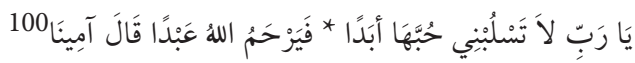

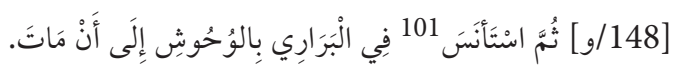

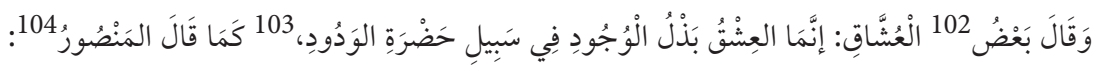

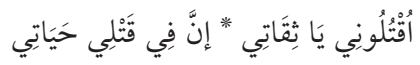

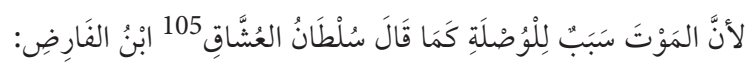

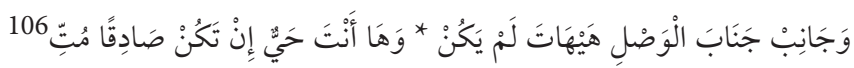

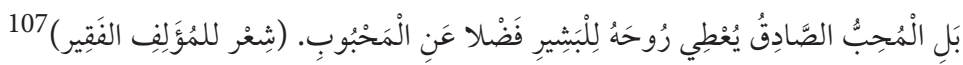

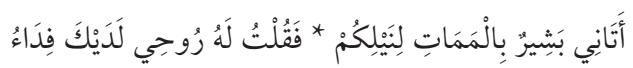

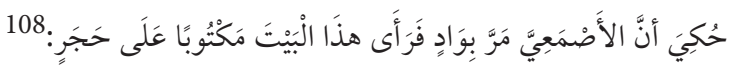

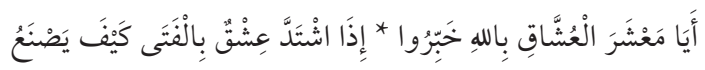

فَكَتَبَ الأَصْمَعِيٌُ تَحْتَهُ:109

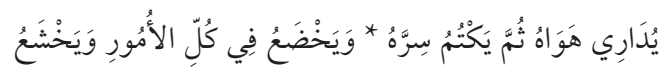

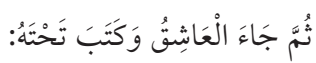

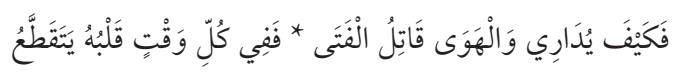

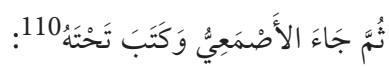

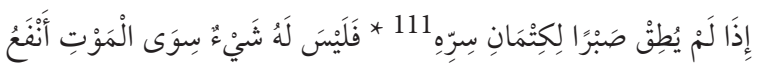

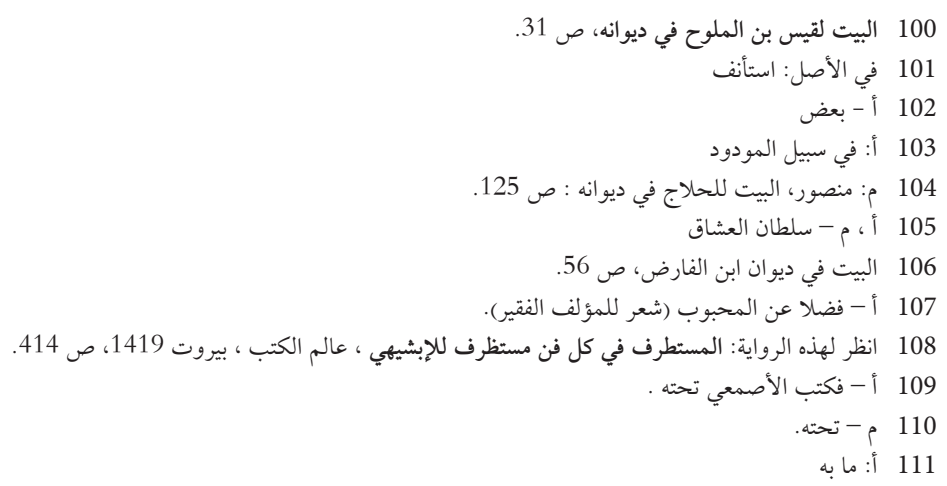




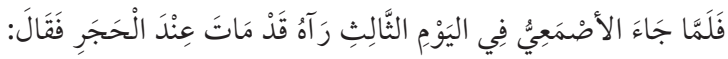

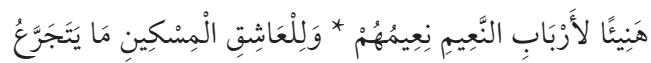

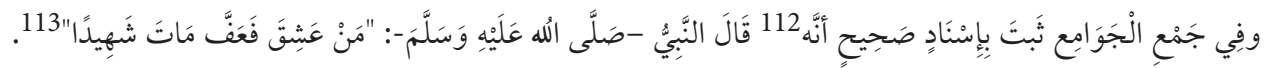

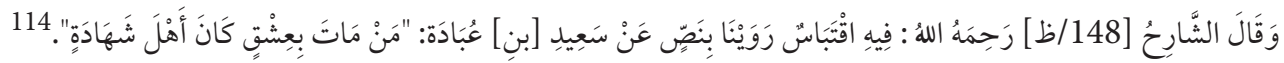

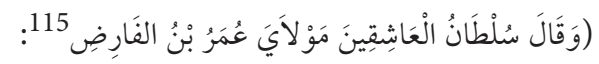

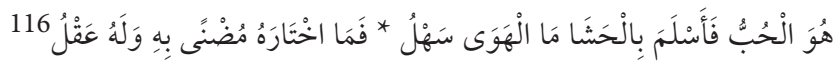

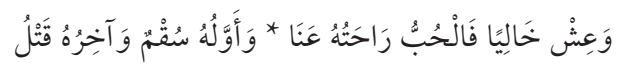

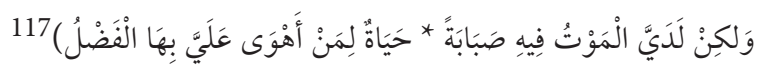

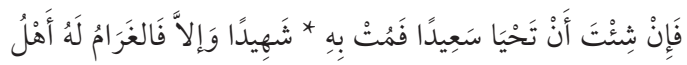

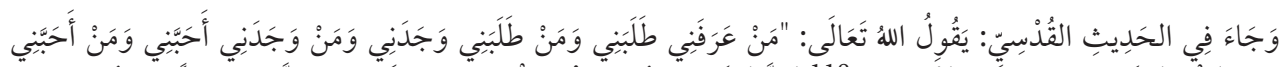

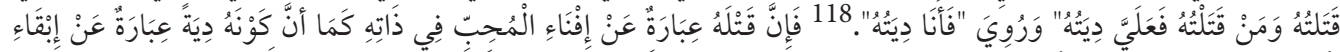

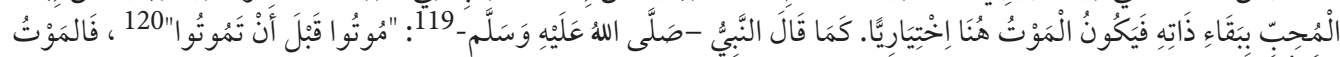

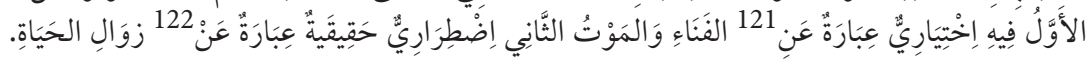

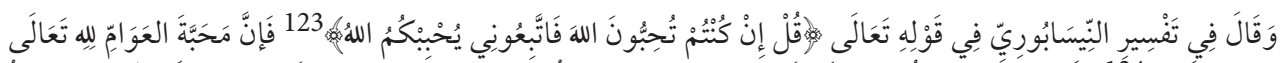

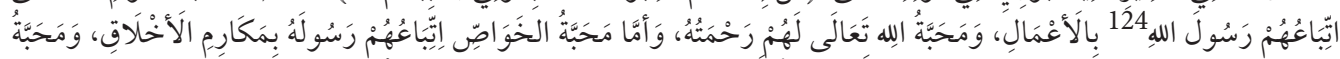

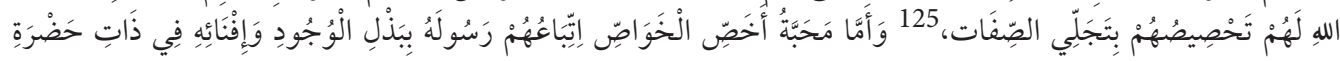

$$
\text { أ - وفي جمع الجوامع ثبت بإسناد صحيح أنها }
$$

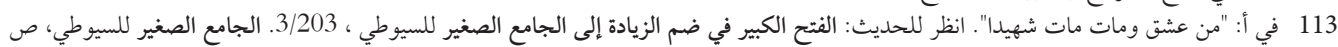

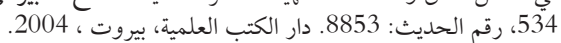

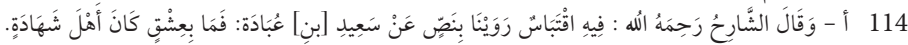

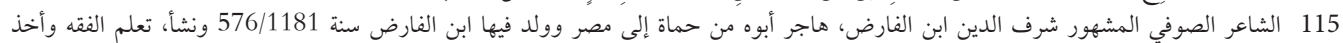

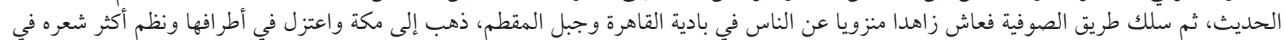

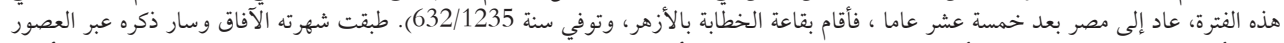

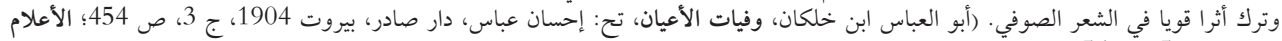

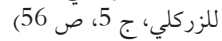
116 الأبيات لابن الفارض في ديوانه: 117

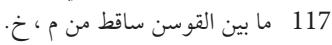

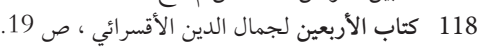
Ali Rıza Kencik, Cemâleddin Aksarâyî ve Ona Nispet Edilen "Erba 'üne Hadīsen” Adlı Eserin Tahkiki (yüksek lisans tezi, 2009), Selçuk Üniversitesi SBE.

عما اشتهر من الأحاديث على ألسنة الناس لإسماعيل بن محمد العجلوني، مكتبة القدسي ، القاهرة 1351. ج 2، ص 291.

$$
119 \text { في خ: كما في قوله -ع م - } 120
$$

120 121 أ: مستعارا من الفناء 120

122

123

124

125 


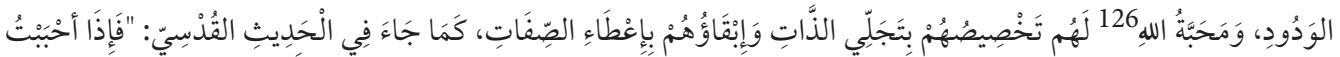

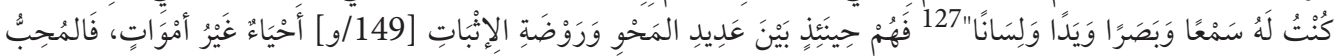

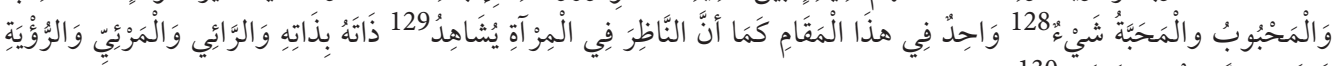

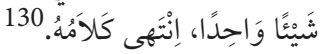

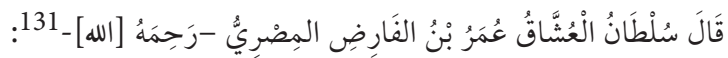

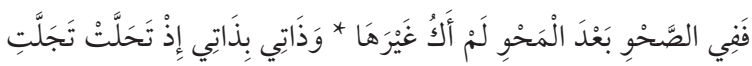

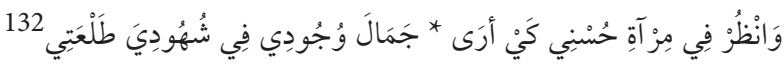

\section{الفَصْلُ الثَّالِثُ 133 فِي إنْكَارِ الْمُتَكَلِّمِينَ وَجَوَابِهِْْ}

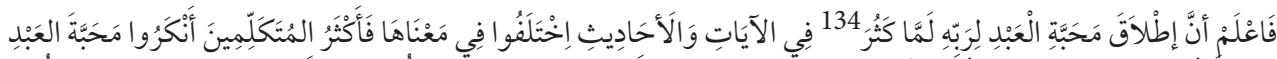

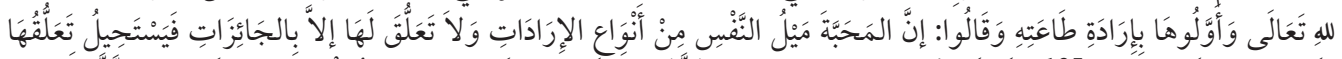

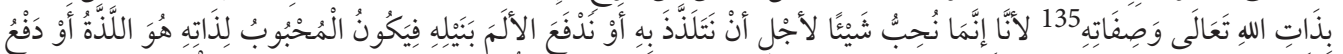

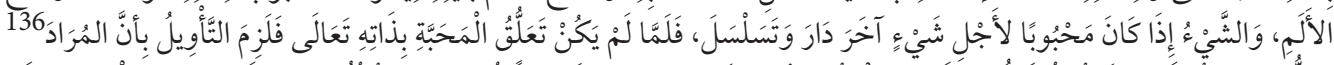

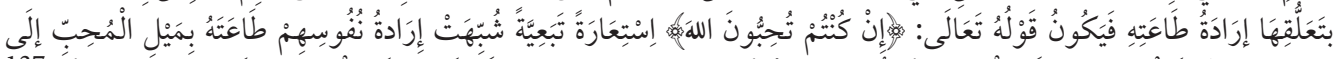

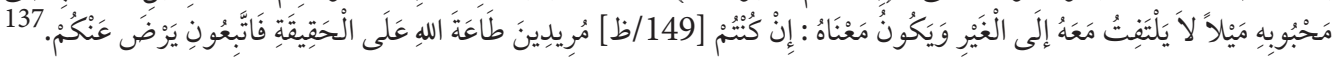

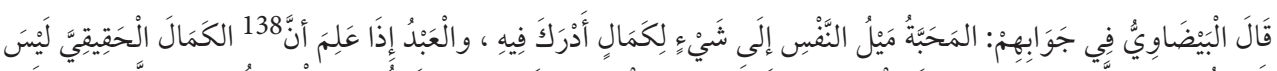

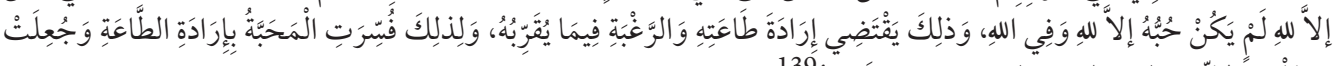

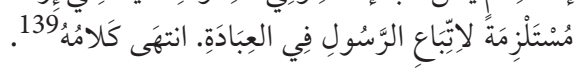

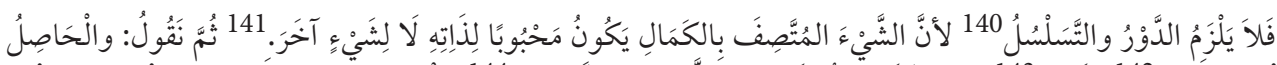

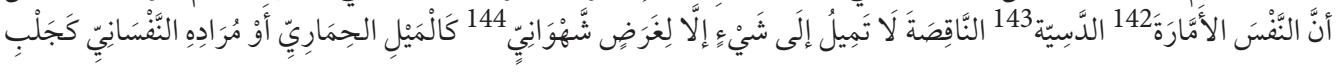

$$
\begin{aligned}
& 126 \text { أ: محبته لهم } \\
& 127 \text { شرح السنة لأبي محمد محيي السنة البغوي، ، (ت: شعيب الأرنؤوط ـ محمد زهير الشاويش)، المكتب الإسلامي، دمشق/بيروت، 1983، ج، ص } 22 . \\
& 128 \\
& 129 \text { أ: ليشاهد } \\
& 130 \text { غرائب القر آن ورغائب الفرقان لنظام الدين القمي النيسابوري، (تح: زكريا عميرات) ، دار الكتب العلمية، بروت } 12916 \text { العرد } 1416 \text { ، ج 1، ص } 348 .
\end{aligned}
$$

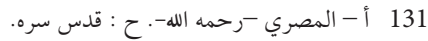

$$
\begin{aligned}
& 132 \text { البيت من تائية ابن الفارض في دئ الهـ } 133 \\
& 133 \\
& 134 \\
& 135 \text { | أخ - وصفاته } \\
& 136 \text { أ - بأن المراد } \\
& 137 \text { أن أشية الشيخ زاده على البيضاوي، ج2، } 20 \\
& 138 \\
& 139 \text { أ - كلامه ، أنوار التنزيل وأسرار التأويل للبيضاوي ، (تح: محمد عبد الرحمن المرعشلي)، دار إحياء التراث العربي، بيروت 1418 ج 2، ص } 13 . \\
& 140 \text { أ - و التسلسل }
\end{aligned}
$$

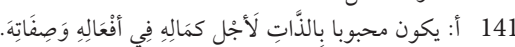

$$
\begin{aligned}
& 142 \text { م - الأمارة } 141 \\
& \text { الد } 143 \\
& 144
\end{aligned}
$$




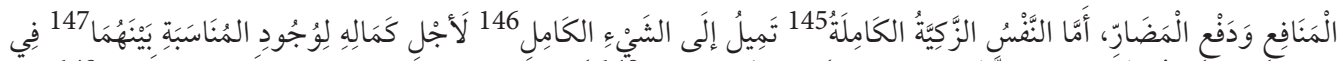

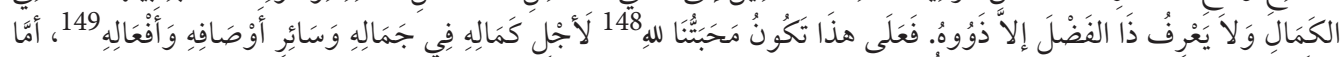

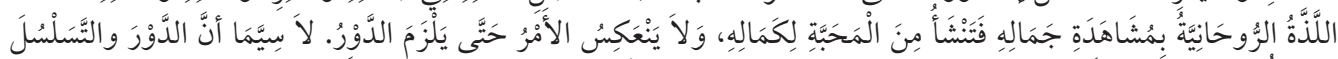

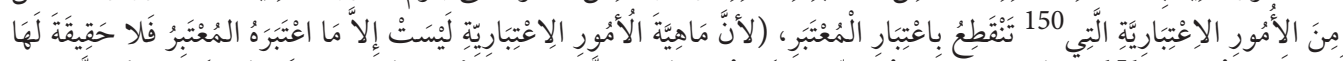

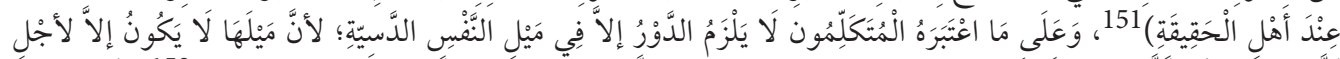

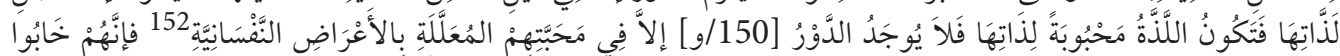

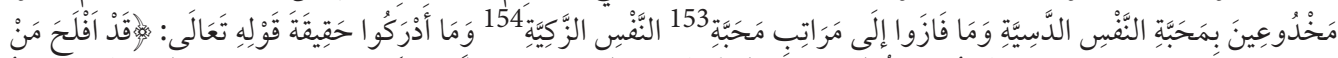

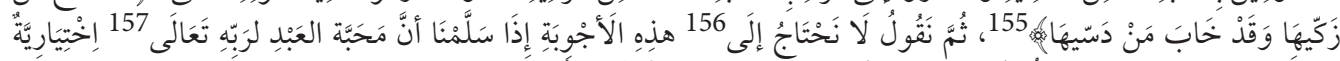

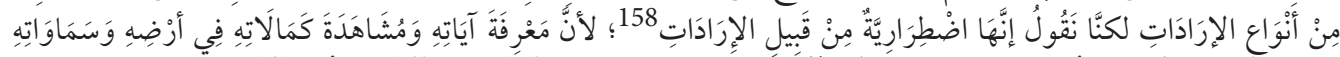

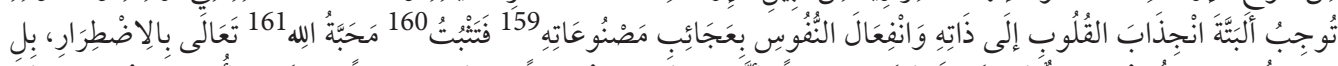

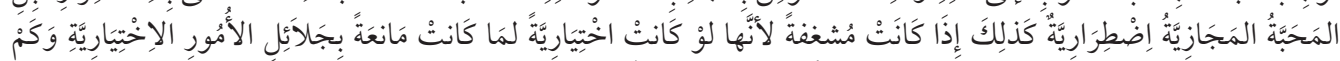

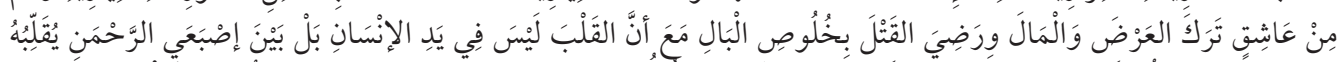

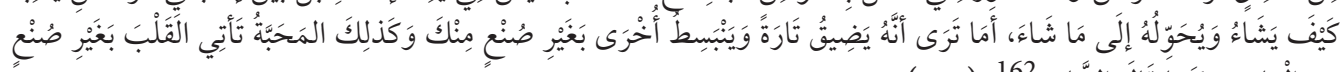

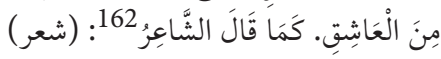

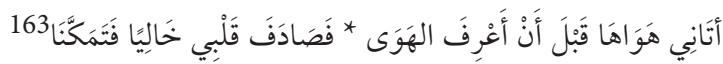

$$
\text { حَتَّى قَالُو الَيْسَ للعَاشِتِقِ قَلْبْ: }
$$

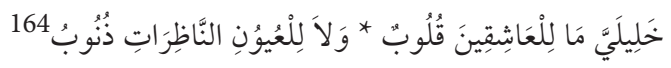

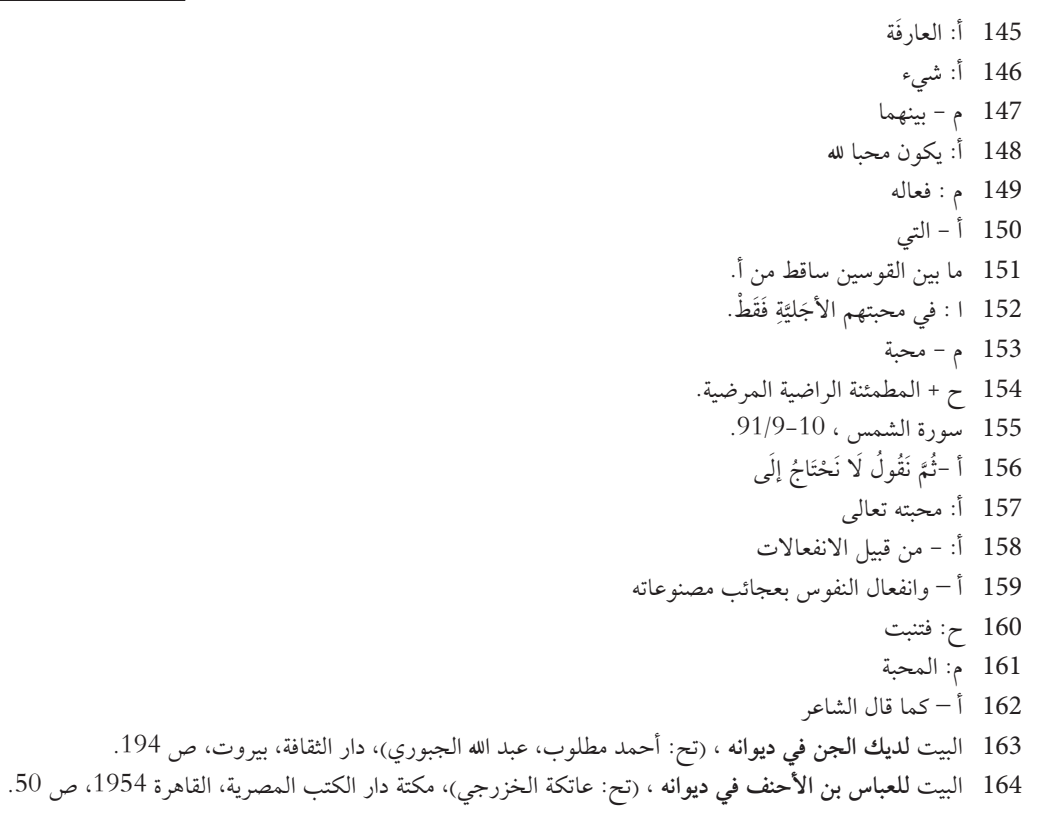


وَقالَ ابنُ الفَارِض:165

كَانَ لِِي قَلْبُ بِجَرْعَاء الحِمَى * ضَاعَ مِنِّي هلْ لَهُ رَدُّ عَلَكَّ 166

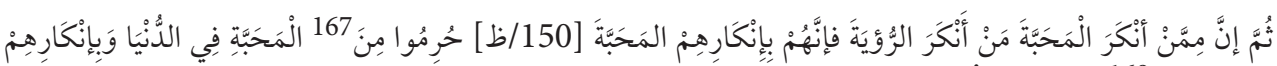

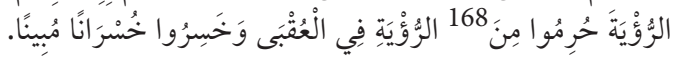

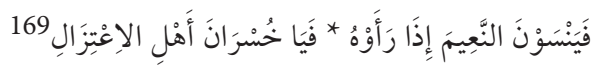

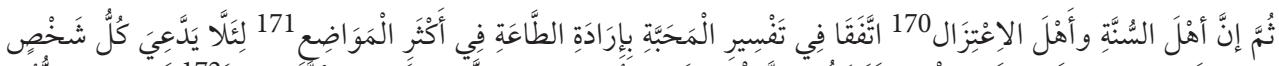

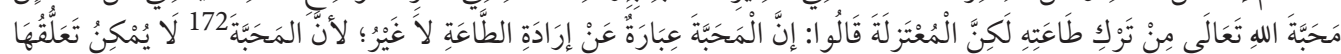

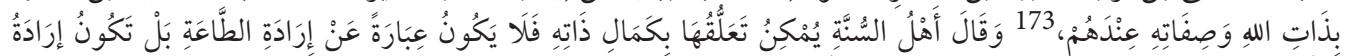

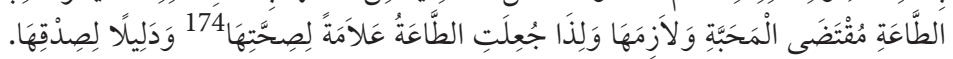

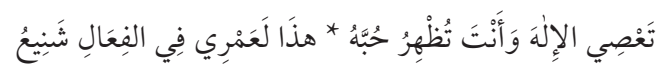

لَوْ كَانَ حُبُبكَ صَادِقًا لَأَطَعْتَهُ * إنَّ الْمُحِبَّ لِمَنْ يُحِبُُ مُطِيعُ 175

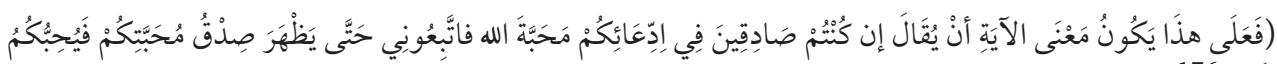

اللهُ تَعَالَّى).

\section{الفَصْلُ الرَّابع فِي جَوَابِ المُحِبِّنَ 177}

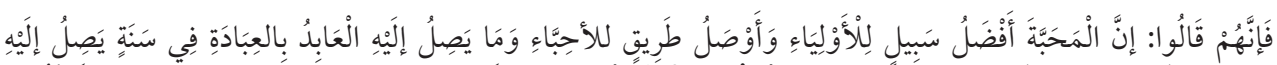

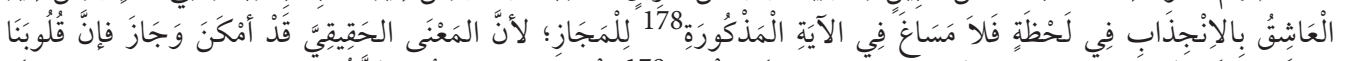

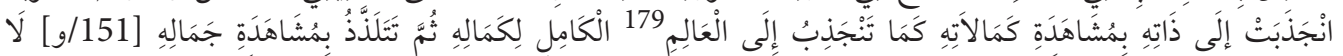

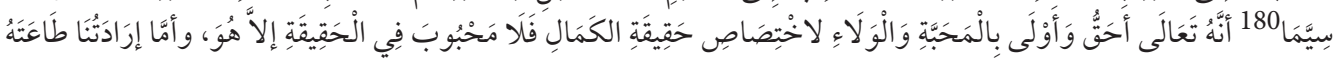

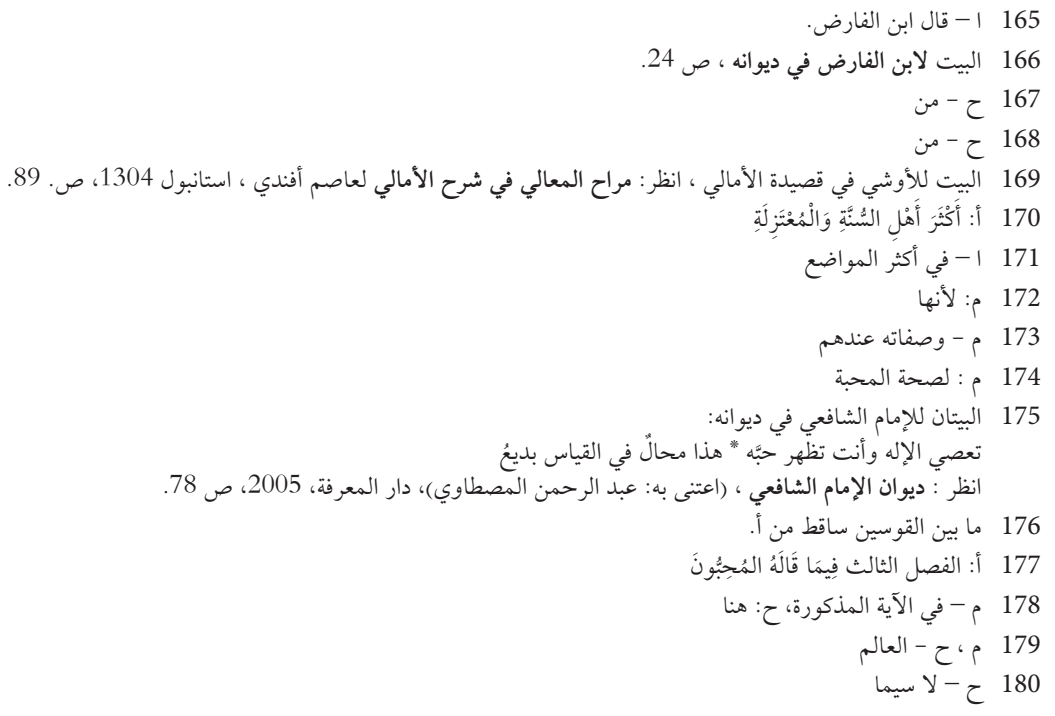




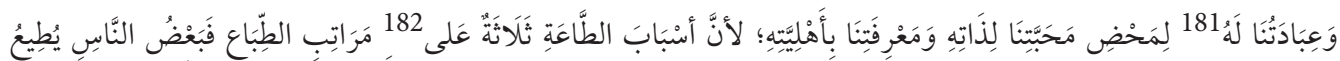

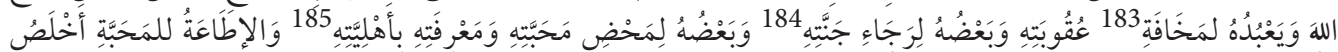

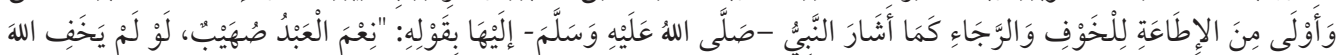

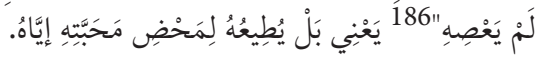

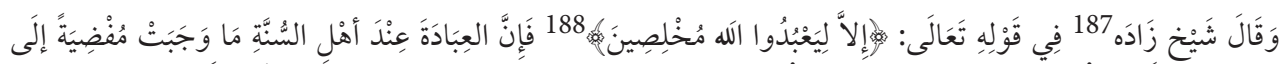

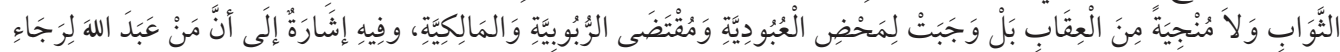

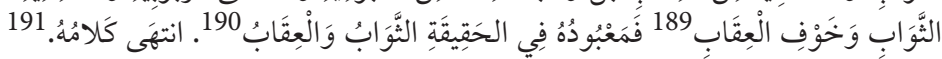

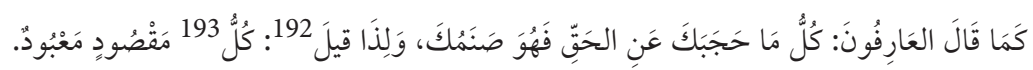

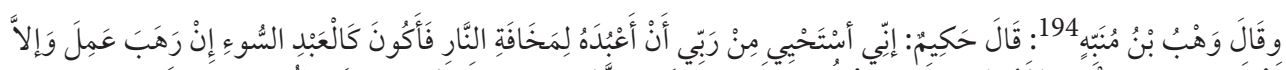

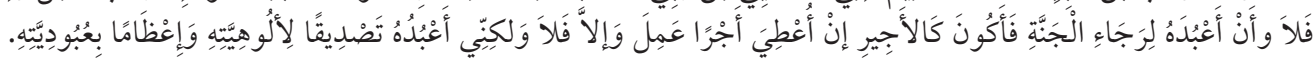

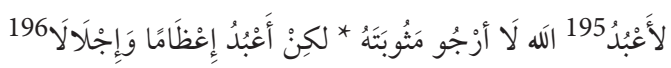

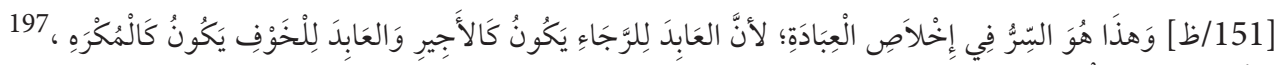

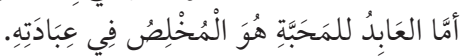

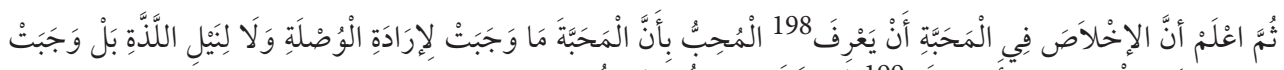

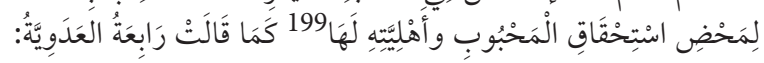

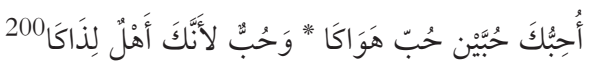




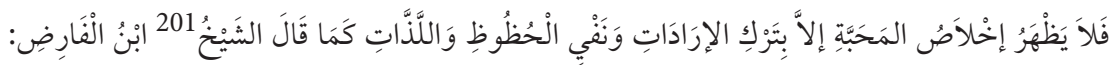

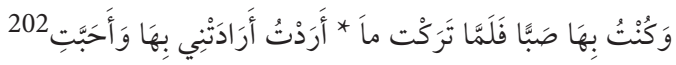

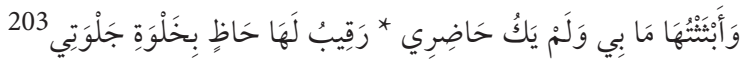

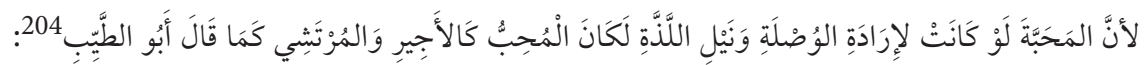

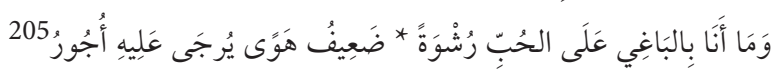

\section{الفَصْلُ الخَامِسُ فِي جَوَابٍ العَارِفِينَ206}

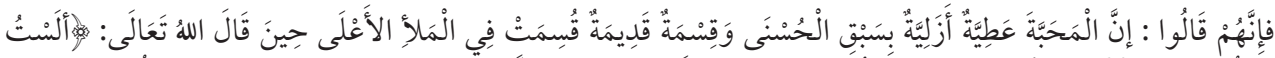

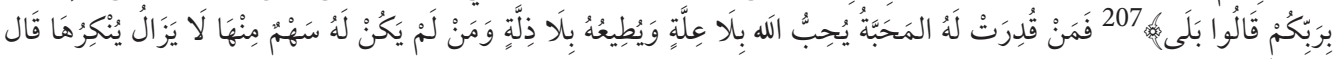

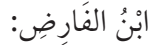

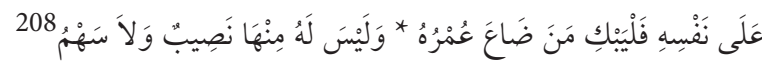

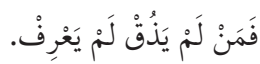

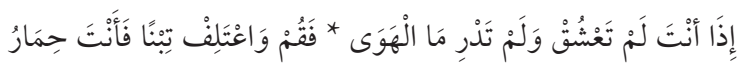

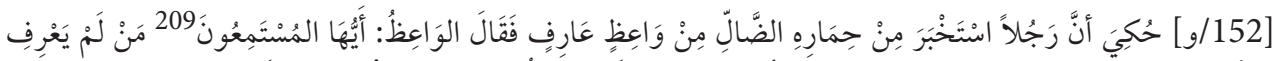

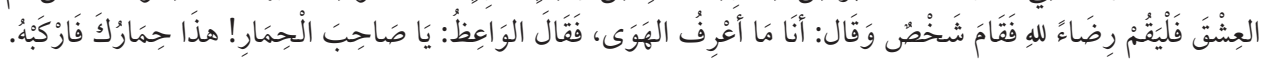

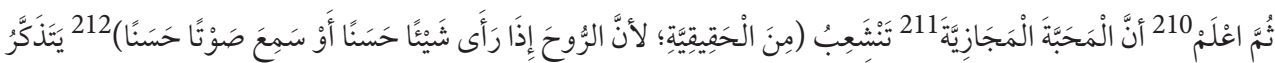

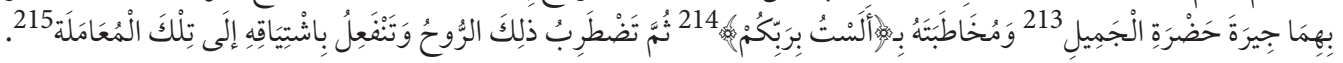

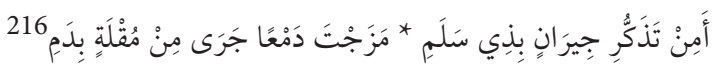

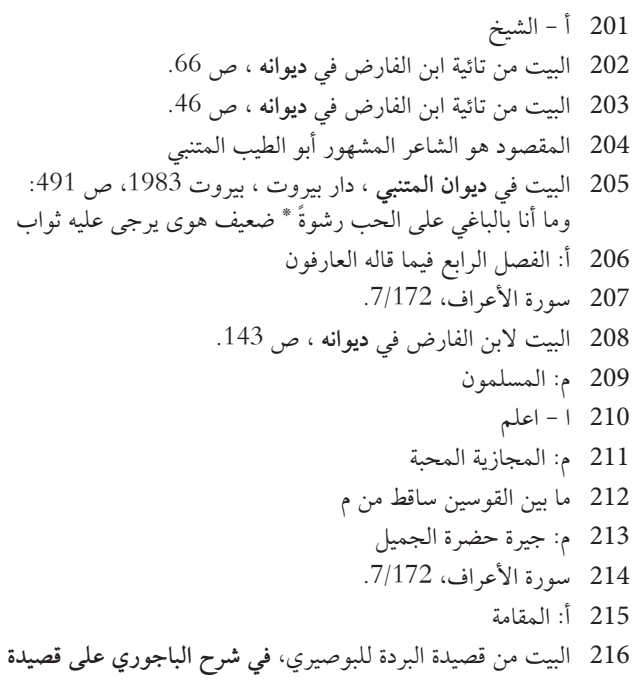




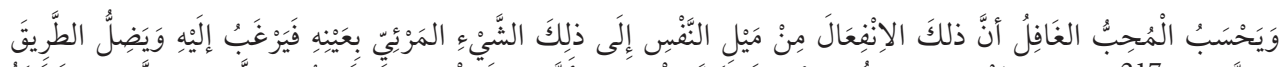

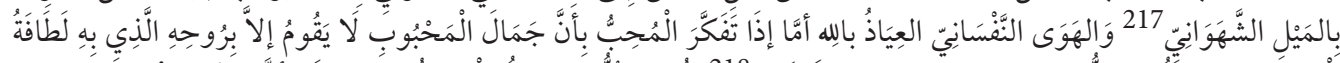

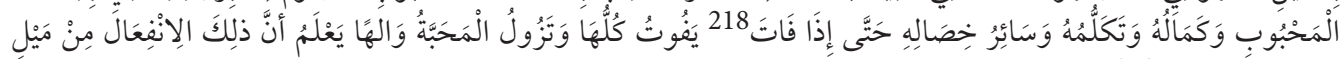

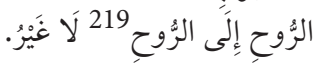

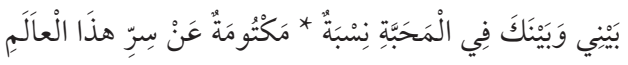

$$
\begin{aligned}
& \text { نَخْنُ اللَّذَانِ تَعَارَفَتْ أَزْوَاحُنَا * مِنْ قَبْلِ خَلْقِ اللهِ طِينَة اَدَمْ }
\end{aligned}
$$

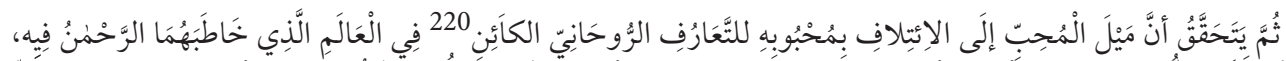

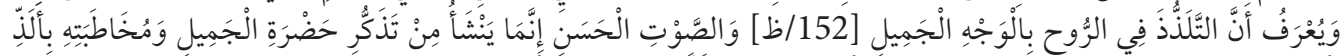

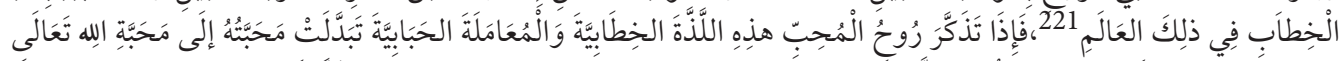

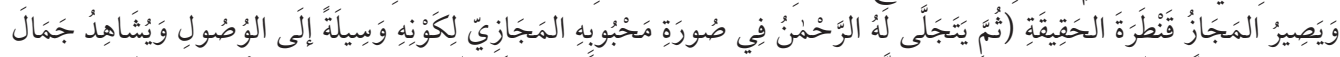

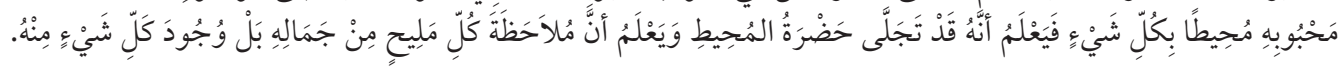

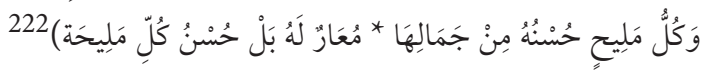

\section{البَابُ الثَّانِي فِي مَحَبَّةِ الرَّبِ لِعَبْدِهِ}

وَفِيهِ أَزْبَعَةُ فُصُولٍِ

\section{الفصلُ الأَوَّلُ 223 فِي الَأدِلَّة الوَارِدَةِ فِي مَحَبَّةِ الوَّبِّ لِعَبْدِهِ 224}

كَمَا قَالَ اللهُ تَعَالَىلى : 225

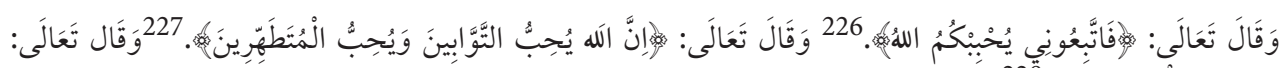
$22 \ddot{8} 22$

$$
\begin{aligned}
& 217 \\
& 218 \\
& 219 \\
& 220 \\
& 221 \text { أ - خَاطَبْهُمَا الرَُّْمنُ فِِه، ويعرف أن التلذذ في الروح بالوجه الجميل والصوت الحسن إنما ينشأ من تذكر حضرة الجميل ومخاطبته بألذ الخطاب في } \\
& \text { ذلك العالم. }
\end{aligned}
$$

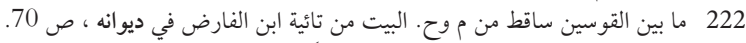

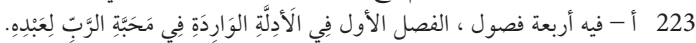

$$
\begin{aligned}
& 224 \\
& 225 \\
& 226 \text { هذه الآية ساقطة من أ ، م. سورة آل عمران: 3/31 آل سورة } \\
& \text { 227 سورة البقرة، 2/222. } \\
& \text { 228 } 227
\end{aligned}
$$




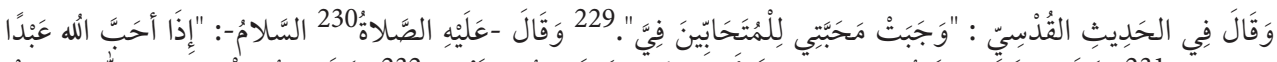

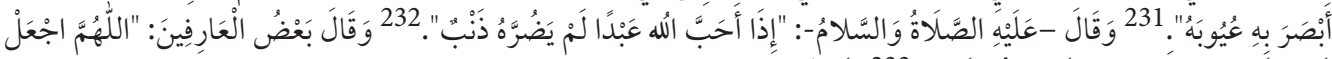

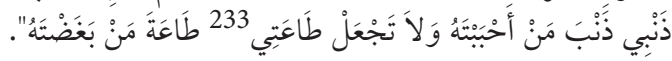

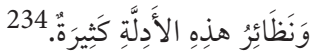

\section{الفصُلُ الثَّانِي 235 فِيمَا قَالَهُ عُلَمَاءُ الشَّرِيعَةِّ}

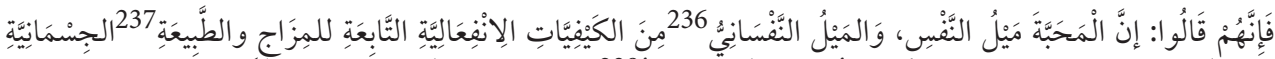

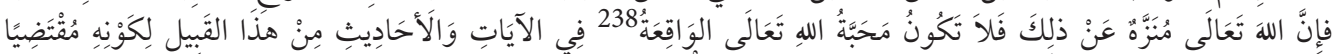

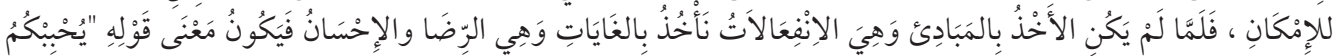

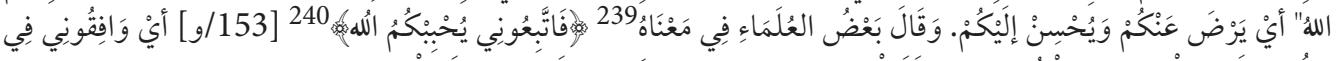

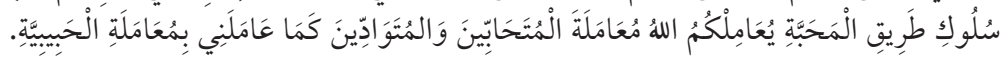

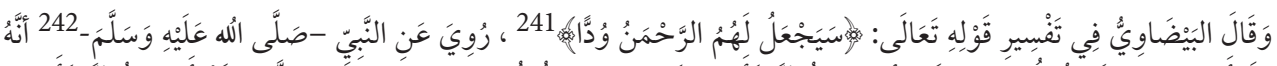

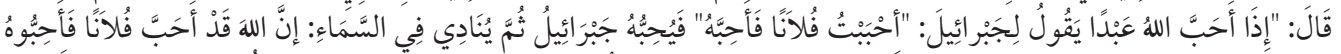

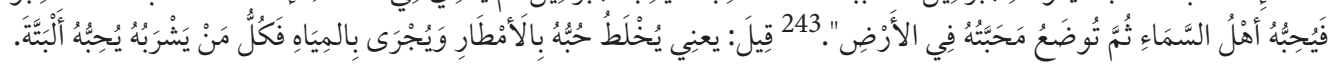

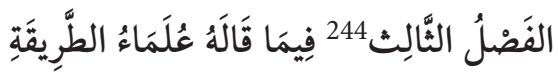

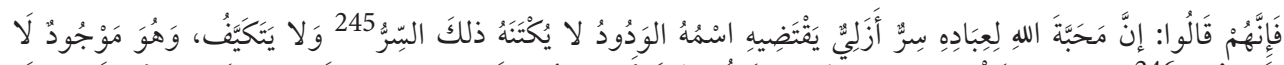

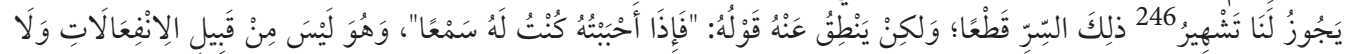

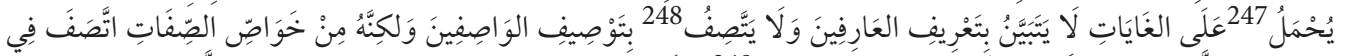

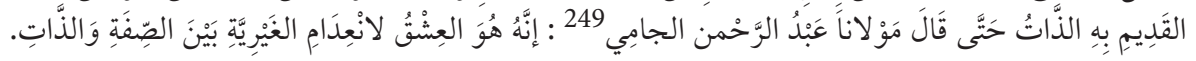

$$
\begin{aligned}
& 229 \text { مسند أحمد بن حنبل، ج 36، ص } 230 \\
& 230 \text { م - الصلاة } \\
& 231
\end{aligned}
$$

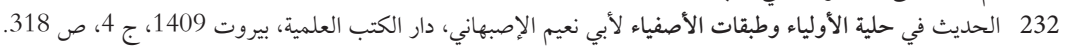

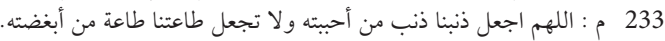

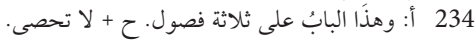

$$
\begin{aligned}
& 235 \text { أ: النصل الأول } \\
& 236 \text { أ - النفساني } \\
& 237 \\
& \text { ( } 238 \\
& 239 \text { ح: قوله تعالى } 238 \\
& 240 \text { سورة آل عمران، 3/31. } \\
& 241 \text { سورة مريم: 19/96. } \\
& 242 \\
& 243 \text { البخاري، بدء الخلق، } 6 . \\
& 244 \\
& 245 \\
& 246 \text { أ: كثف ألف } \\
& 247 \text { أ + ذلك } \\
& 248 \\
& 249 \text { أ: حتى قيل ؛ عبد الرحمن بن أحمد الجامي من علماء ما وراء النهر ومتصوفيها، توفي سنة 898/1492 في هراة، اشتهر بنظمه ونثره، من كتبه: الفوائد }
\end{aligned}
$$




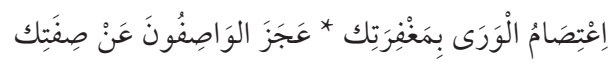

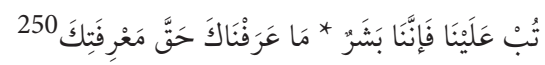

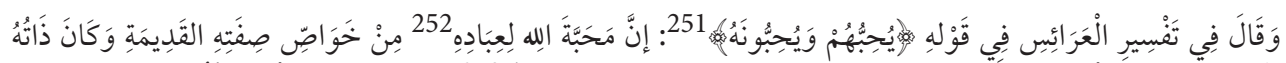

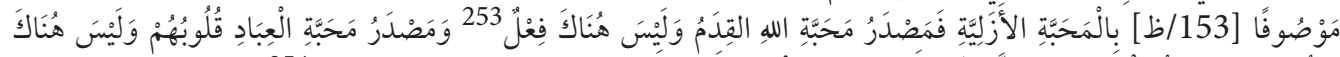

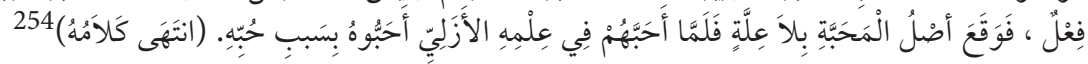

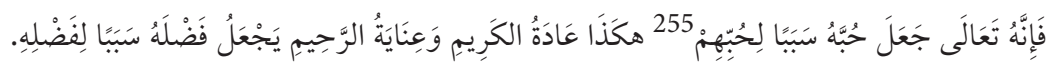

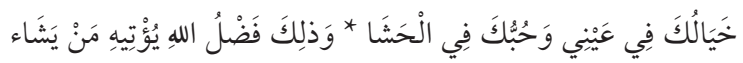

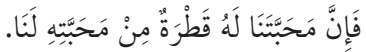

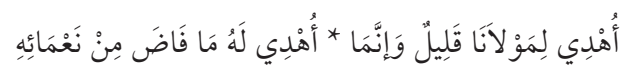

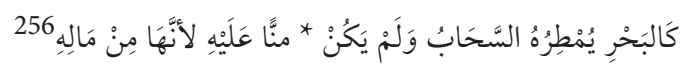

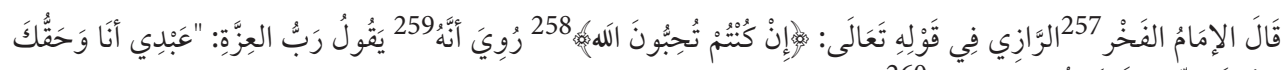

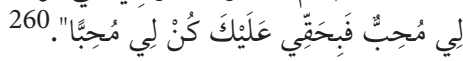

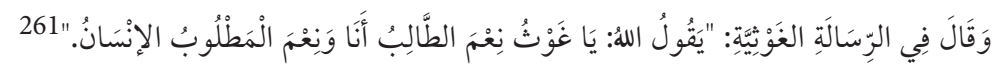

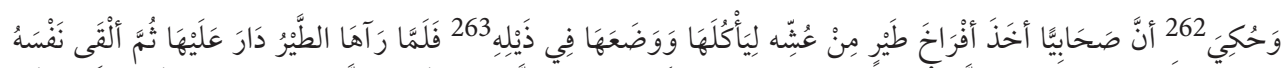

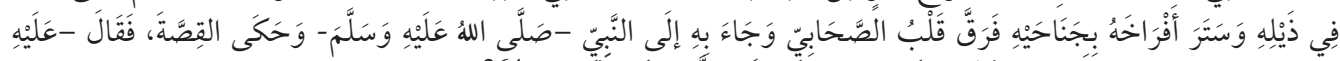

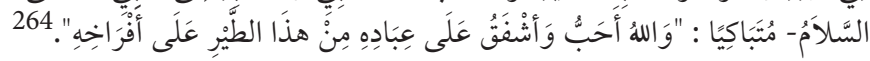

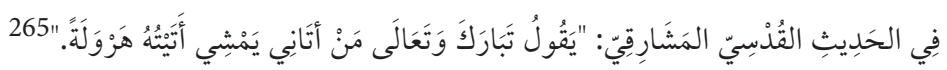

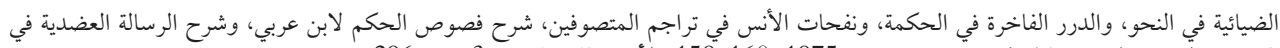

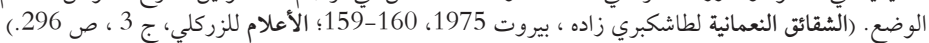

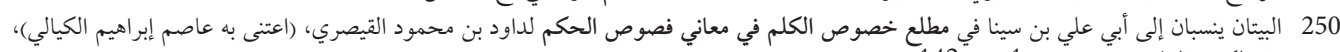

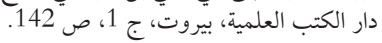
251 سورة المائدة، 5/54. م م - في قوله "يحبهم ويحبُونه" 252 253 254 عرائس البيان في حقائق القر آن لأبي محمد صدر الدين روزبهان البقلي ، (تح: أحمد فريد المجيدي)، دار الكتب العلمية، بيروت 2008، ج 1، ص 318. 255 256 البيتان ينسبان إلى البديع الأسطر لابي في وفيات الأعيان وأنباء أبناء الزمان لابن خلكان، (تح: إحسان عباس)، دار صادر، بيروت 1994، ج 6 ، ص 50. 257 أ: فخر

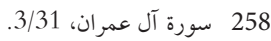
259

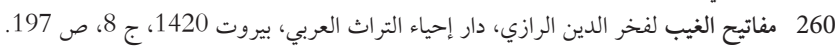

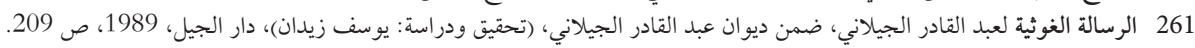
262 263 264 265 في أ هذه الرواية وضعت في الهامش. سنن ابن ماجه ، الأدب، 58.
} 


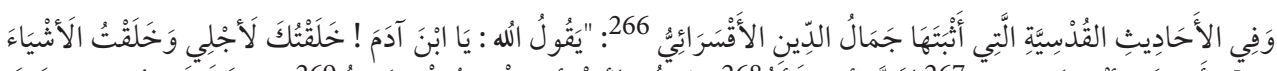

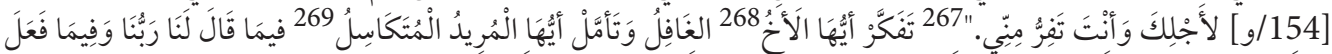

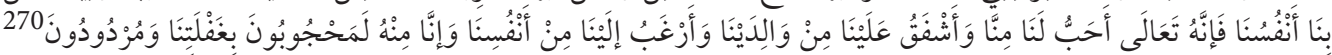

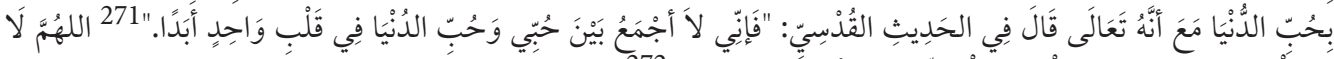

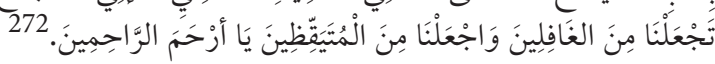

\section{الفَصْلُ الرَّابع 273 فِيمَا قَالَهُ عُلَمَاءُ الحَقِيقَةِّة}

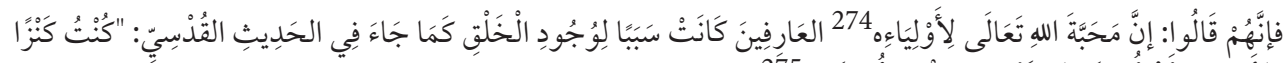

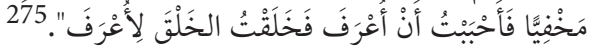

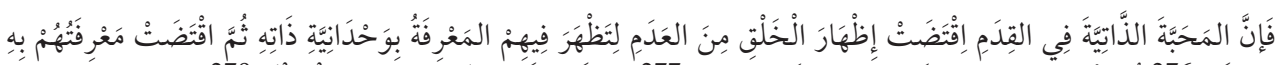

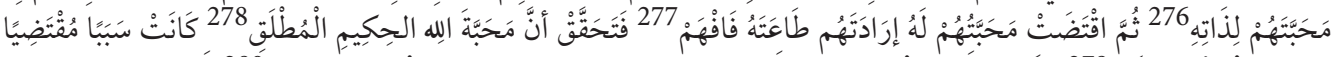

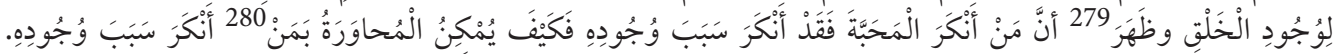

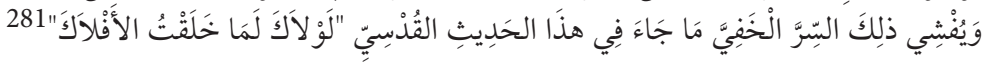

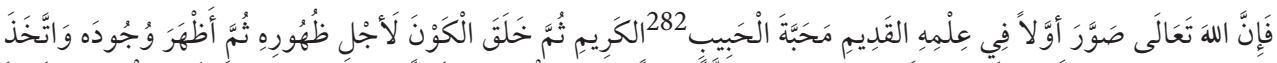

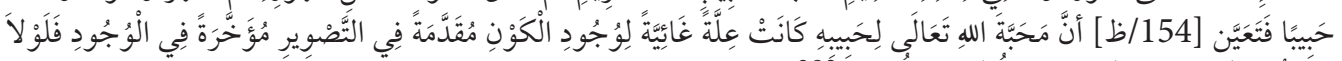

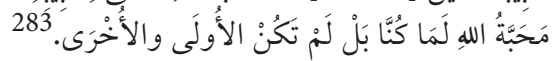

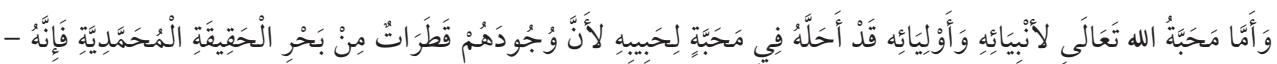

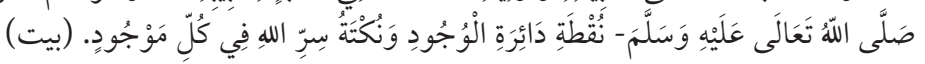

267 ورد الحديث في "كتاب الأربعين لجمال الدين الأقسرابي"، ص 14. وهو جمال الكال الدين محمد الأقسرائي من علماء الدولة العثمانية، اشتهر بمؤلفاته في

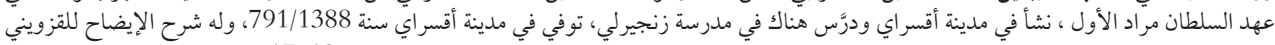

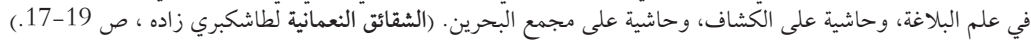

268 269 أ- وتأمل أيها المريد المتكاسل 270

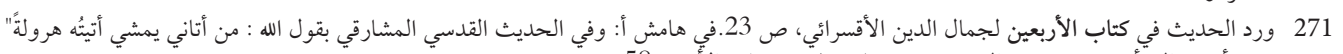

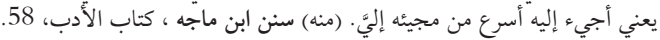
272 273 ا: الفصل الثالث 274

275 قال العجلوني: وفي لفظ "نتعرفت إليهم فبي عرفوني" ، قال ابن تيمية ليس من كالام النبي -صلى الله عليه وسلم - ولا يعرف له سند صحيح ولا ضعيف.

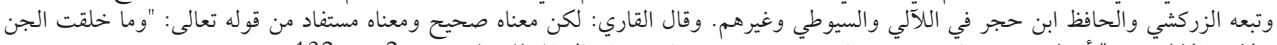

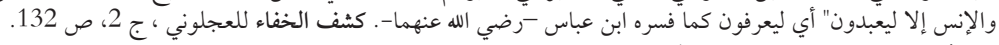
276

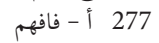
278 م: الحق الحقان 278 279 280

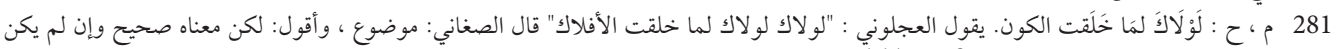

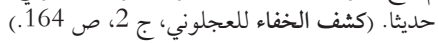
282 283 


\section{لَوْلاَ جَنَابُ حَبيب اللهِه مَا بَرَرت * 284}

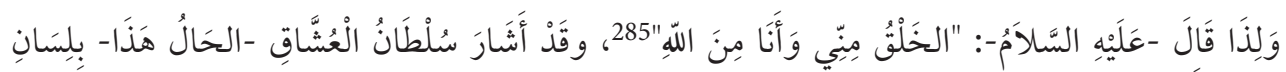

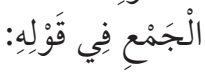

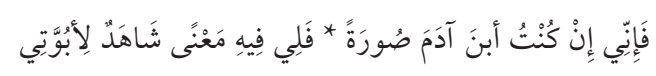

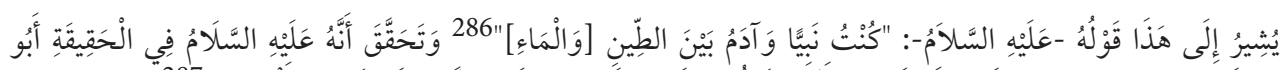

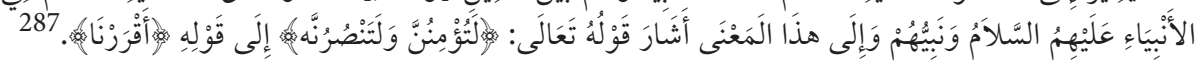

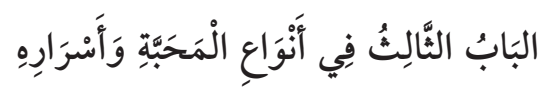

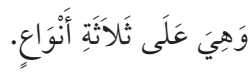

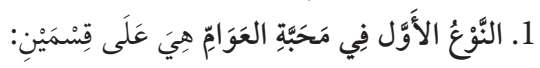

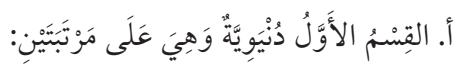

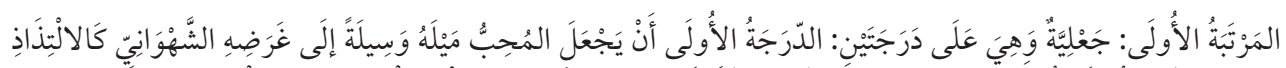

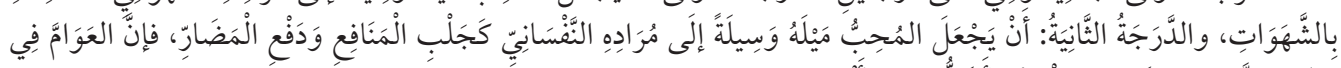

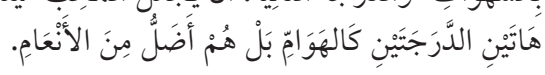

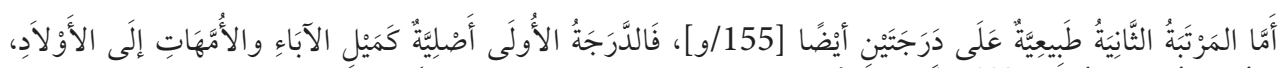

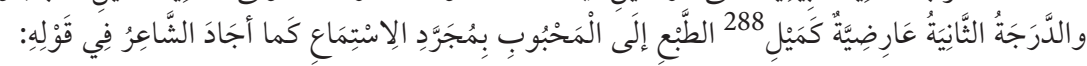

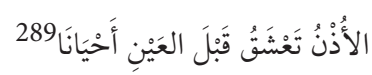

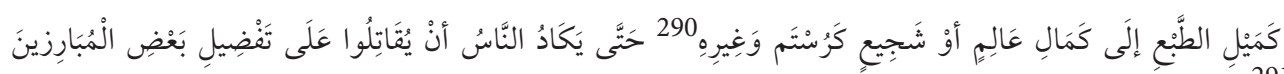
عَلَى 291 بَعْضِ

$$
\begin{aligned}
& 284 \text { في نونية خضر بك بيت يشبه عجزه عجز هذا البيت: }
\end{aligned}
$$

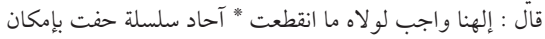

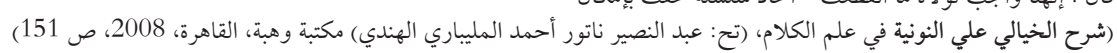

$$
\begin{aligned}
& 285
\end{aligned}
$$

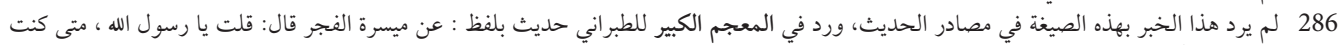

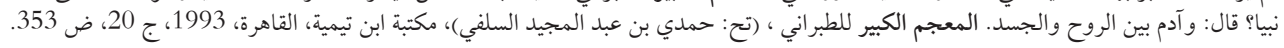

287

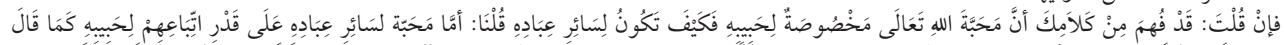

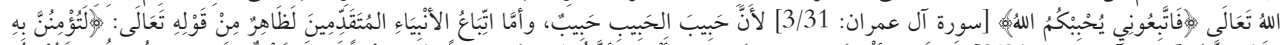

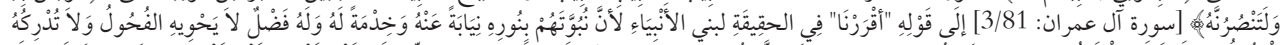

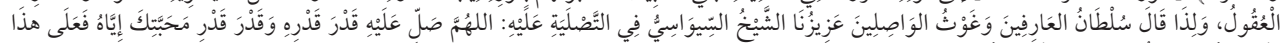

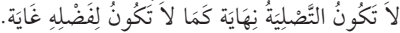
288

289

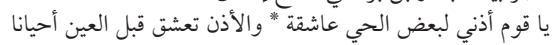

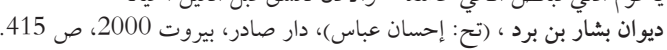

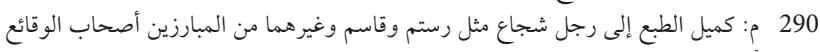




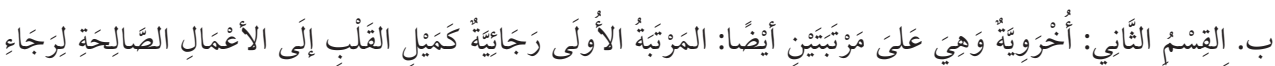

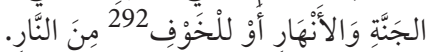

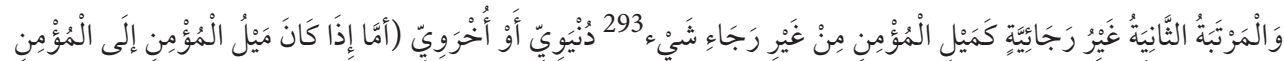

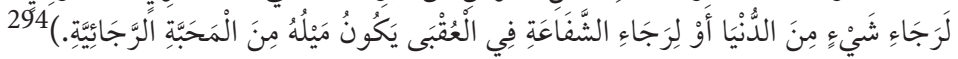

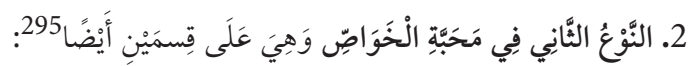

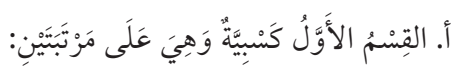

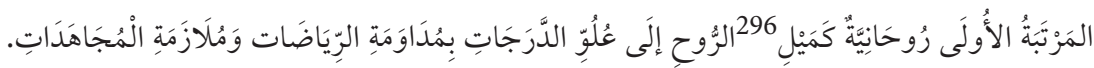

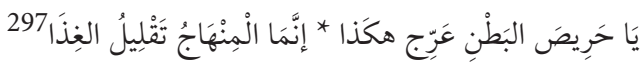

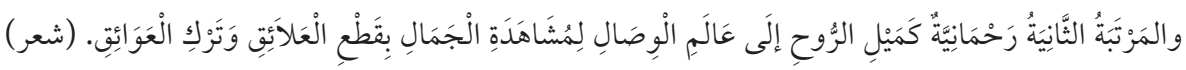

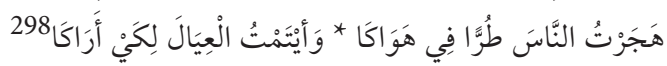

بـ. القِسْمُ الثَّانِي وَهْبِيَّةُ299 كَمَا قَالَ ابْنُ الفَارِضِ : [155/ظة

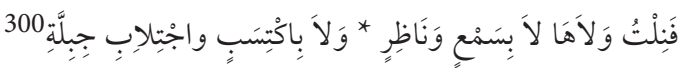

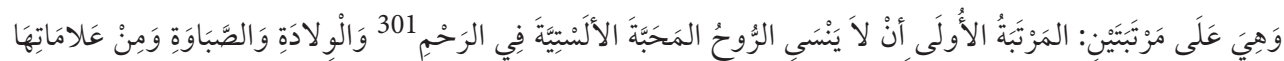

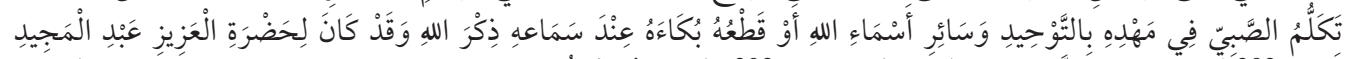

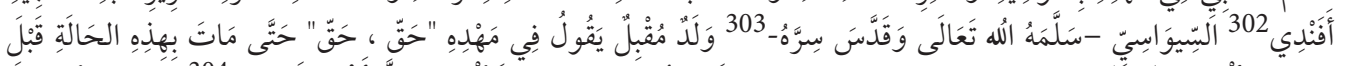

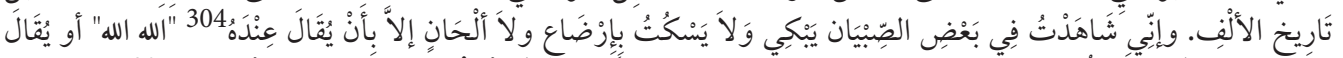

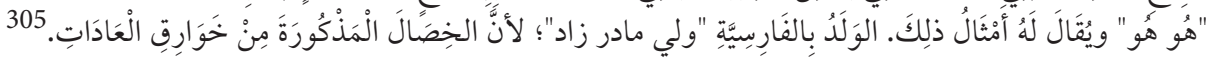

292 أبيء 294 ما بين القوسين ساقط من م و الأح، وفي نسخة م : أما إذا كانت من المرتبة الأولى. وفي نسخةح : أما إذا كانت لرجاء الشفاعة في الآخرة كانت من المرتبة الأولى من الأخروية.

295

296

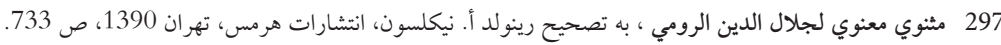

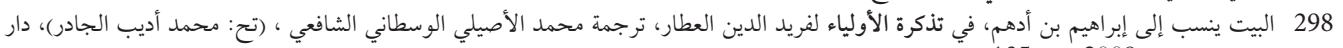

المكتبي، دمشق 2009، صالبئ ص 135. 299 أ: ماهيته 300 301

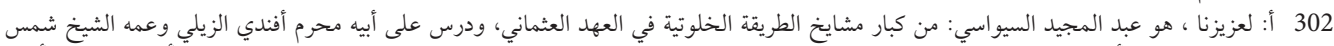

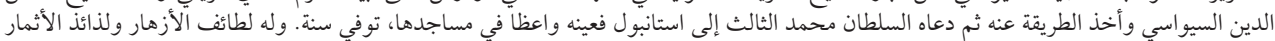

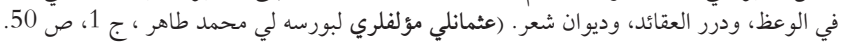
303 


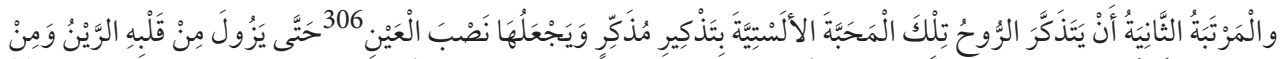

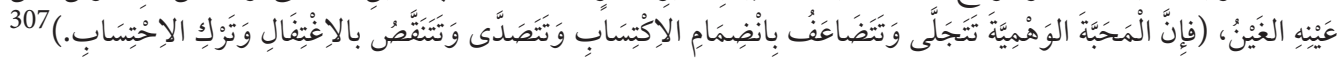

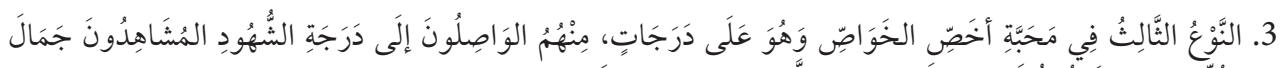

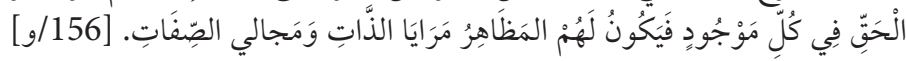

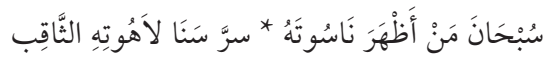
ثُمَّ بَدَا فِي خَلْقِهِ ظَاهِرَا * فِي صُورَةِ الآكِلِ وَالشَّارِب 308

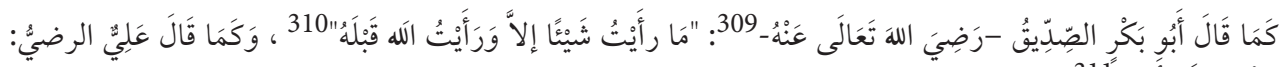

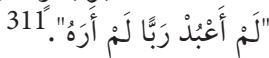

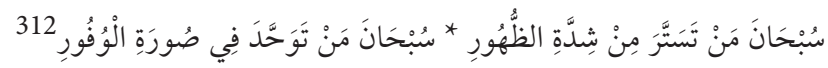

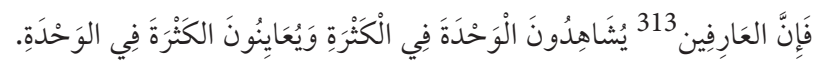

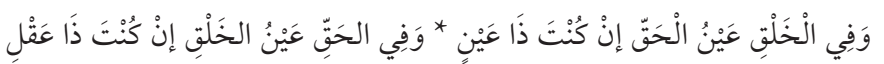

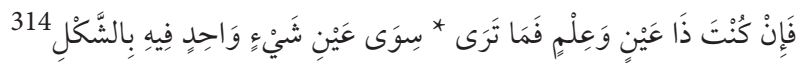

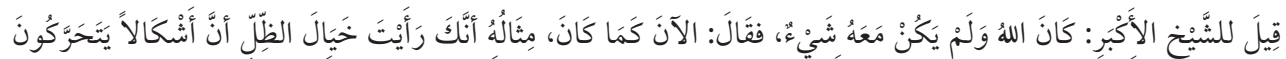

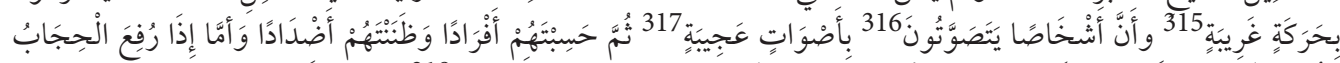

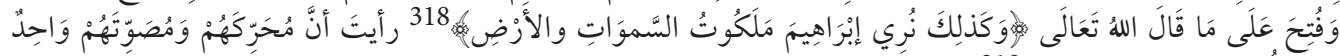

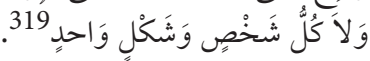

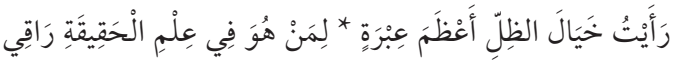

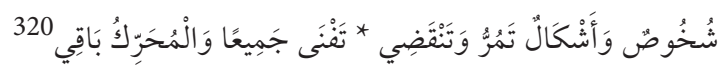

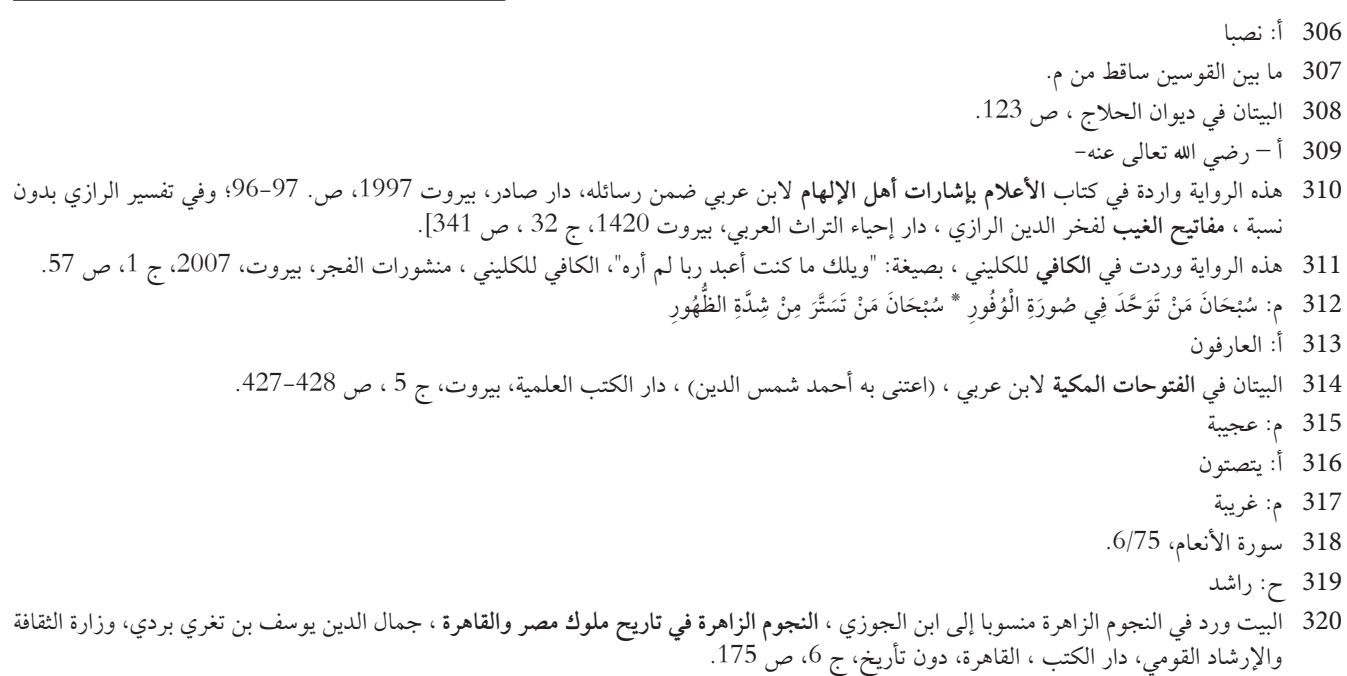




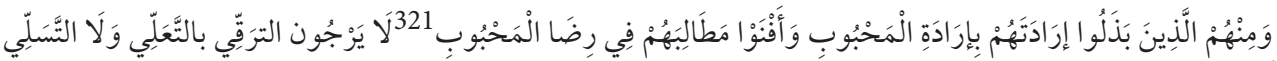

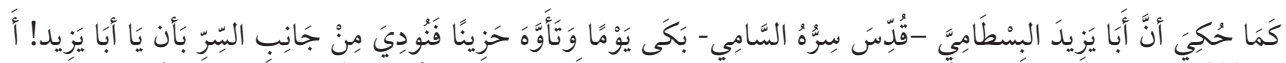

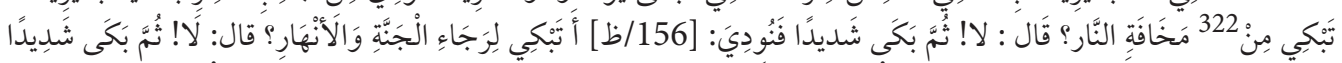

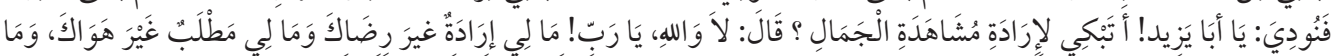

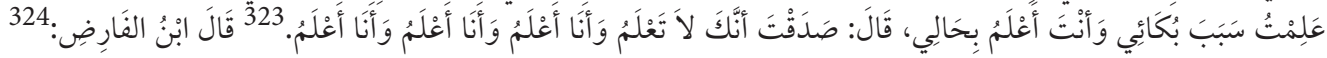

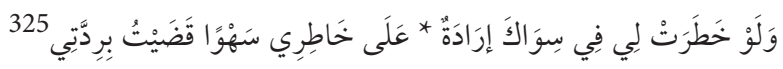

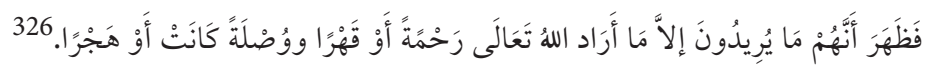

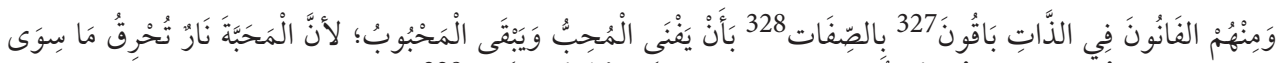

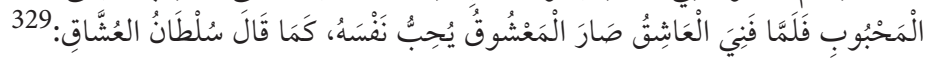

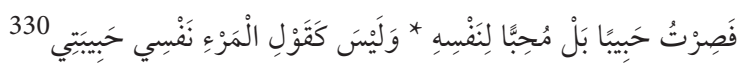

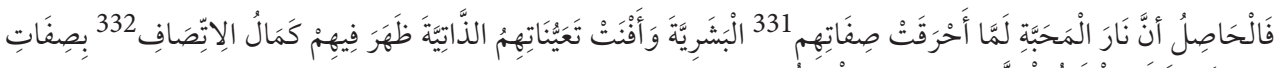

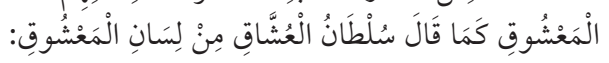

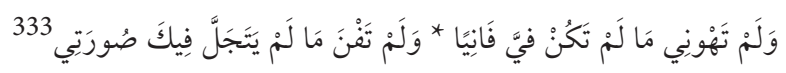

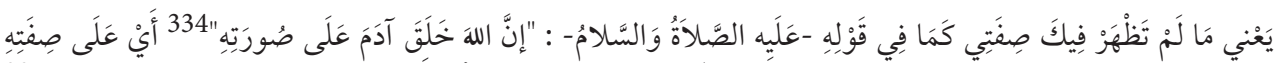

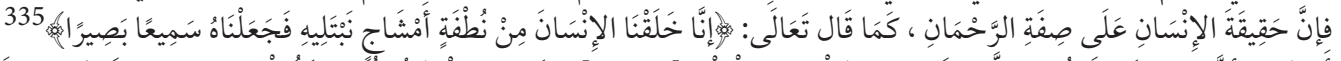

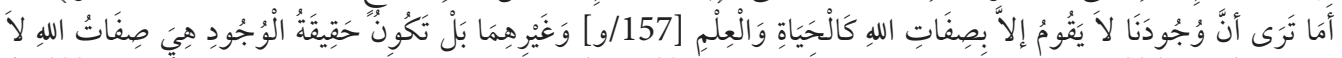

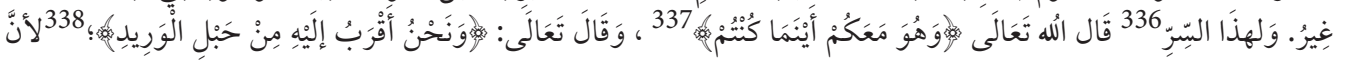

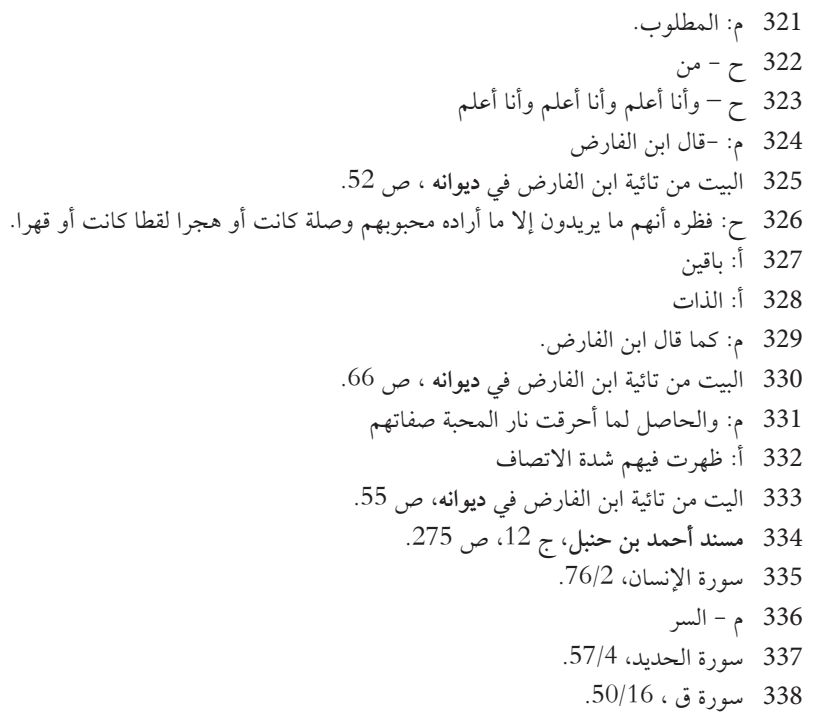




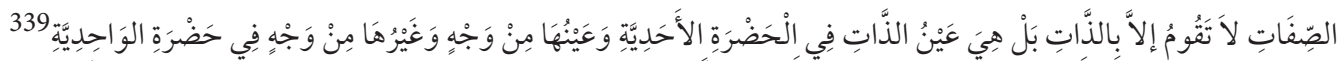

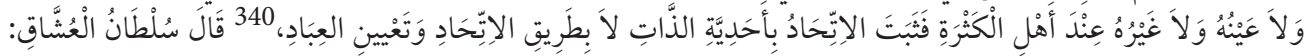

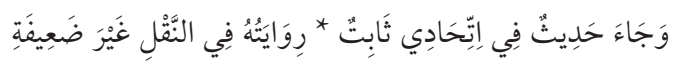

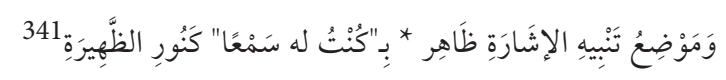

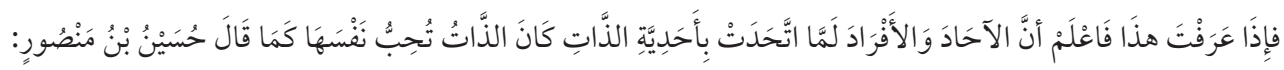

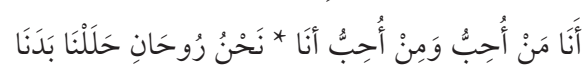

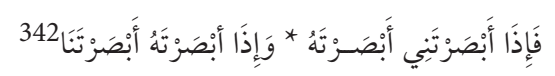

$$
\begin{aligned}
& \text { (وَقَالَ مَوْلانَا جَلالَُ الدِّينِ الرُّومِيٌُ: }
\end{aligned}
$$

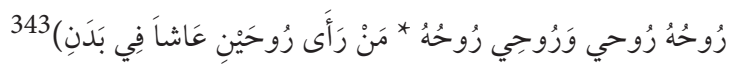

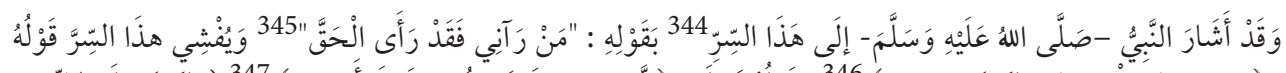

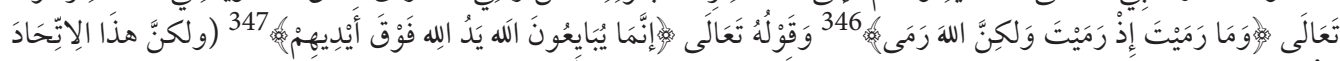

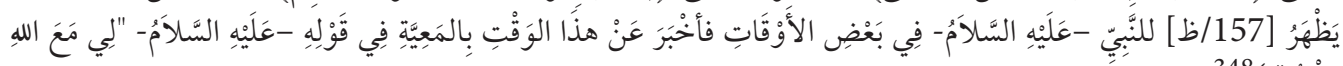

وَقْتُ"

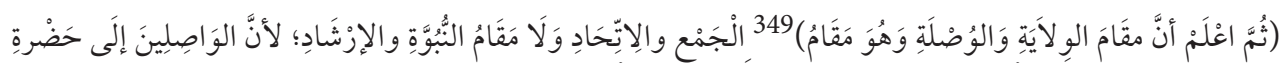

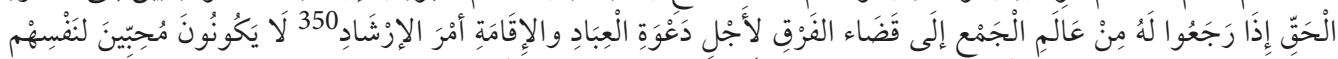

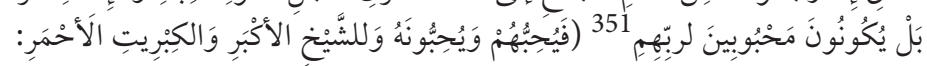

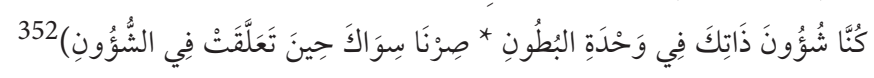

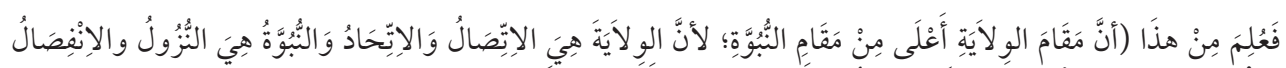

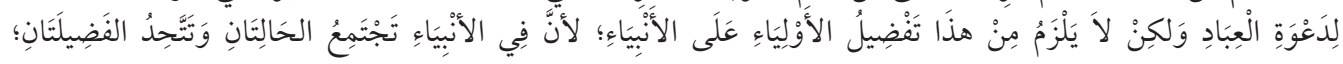

$$
\begin{aligned}
& 339340
\end{aligned}
$$

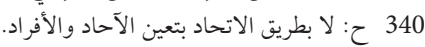

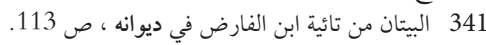

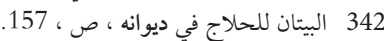

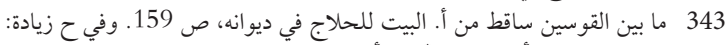

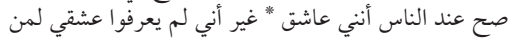

$$
\begin{aligned}
& 344 \text { م: إلى هذا الاتحاد } \\
& 345 \text { البخاري، كتاب التعبير، } 10
\end{aligned}
$$

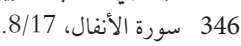

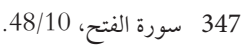

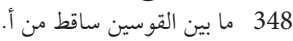

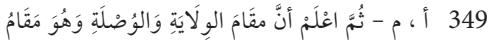

$$
\begin{aligned}
& 350 \\
& 351 \\
& 352 \text { ما بين القوسين ساطق من ح وفيها زيادة: كما كان نبينا عليه السلام حبيب الله. }
\end{aligned}
$$




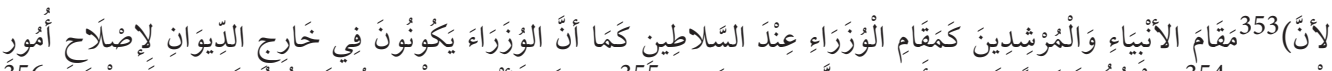

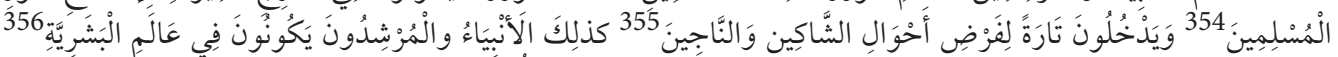

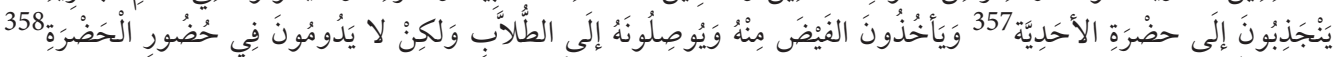

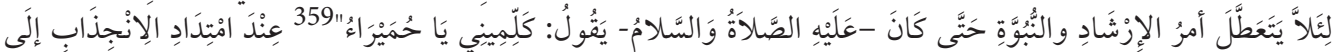

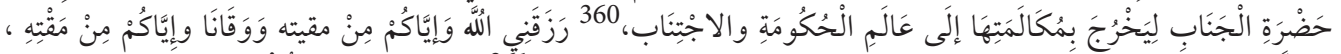

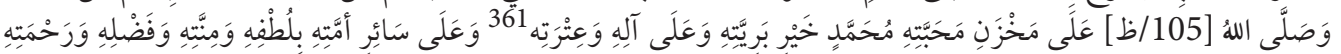

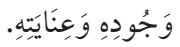

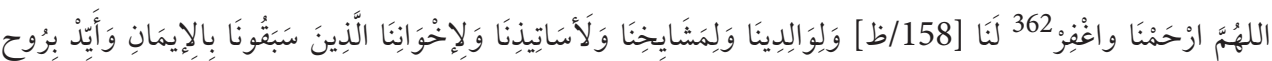

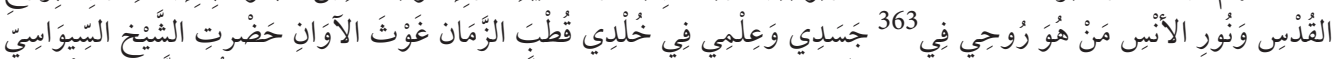

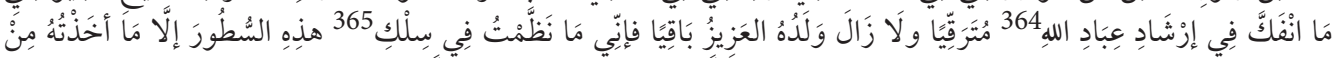

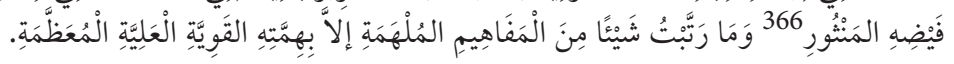

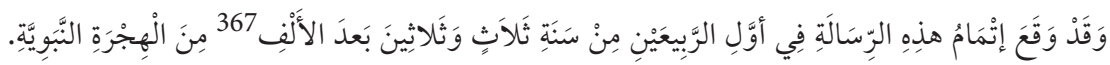

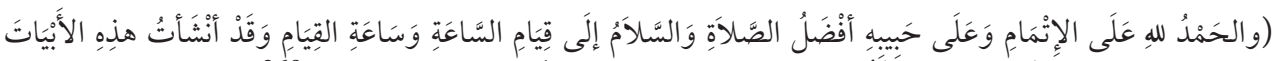

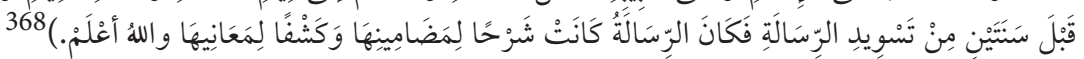

$$
\begin{aligned}
& 353 \\
& 354 \text { ح: الخلق } \\
& 355 \text { م: الشاكرين } \\
& 356 \text { أ - يكونون في عالم البشرية. } \\
& 357 \text { أ: الجناب } \\
& 358 \text { م: في حضرة الملك الوهاب } \\
& 359 \text { لم نقف على هذه الرواية في مراجع الحديث ، ولكنه ورد في تفسير النيسابوري، ج 2، ص } 450 \text { مابك } 402 .
\end{aligned}
$$

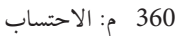

$$
\begin{aligned}
& 361
\end{aligned}
$$

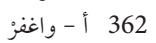

$$
\begin{aligned}
& 363 \text { م م- في } \\
& 364 \\
& 365 \text { أ - في سلك العياد } 366 \text { م الك } \\
& 366 \text { م: الثنور ، 'ح: المنشور } \\
& 367 \text { أ: وألف الثن ع حن } \\
& 368 \text { ما بين القوسين ساقط من م. }
\end{aligned}
$$




\section{المصادر العربية}

أبو العلاء وما إليه لعبد العزيز الميمني الراجكوتي، دار الكتب العلمية، بيروت 1424.

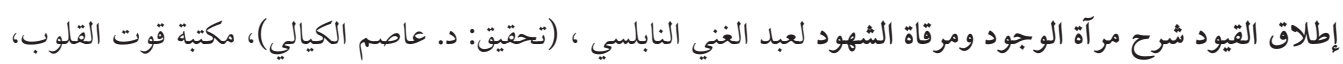
بيروت 2017.

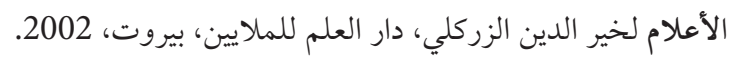

أنوار التنزيل وأسرار التأويل للبيضاوي، (تح: محمد عبد الرحمن المرعشلي)، دار إحياء التراث العربي، بيروت 1418.

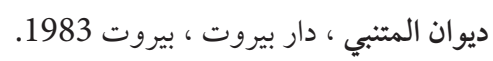
تذكرة الأولياء لفريد الدين العطار، ترجمة محمد الأصيلي الوسطاني الشافعي ، (تح: محمد أديب الجادر)، دار المكتبي، دمشق 2009. التذكرة بأحوال الموتى وأمور الآخرة لأبي عبد الله محمد القرطبي، (تح: الصادق بن محمد بن إبراهيم)، مكتبة دار المنهاج؛ رياض 2004.

التعرف لمذهب أهل التصوف للكلاباذي، (نشر: أحمد شمس الدين) دار الكتب العلمية، بيروت 1993.

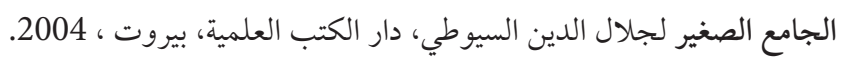

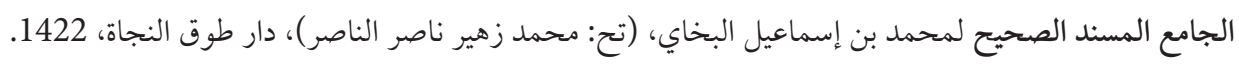

$$
\begin{aligned}
& \text { حاشية شيخزادة على البيضاوي، مكتبة الحقيقة، استانبول ، } 1998 . \\
& \text { الحب في التراث العربي لمحمد حسن عبد الله، عالم الكتب ، الكويت } 1980 . \\
& \text { حلية الأولياء وطبقات الأصفياء لأبي نعيم الإصبهاني، دار الكتب العلمية، بيروت } 1409 . \\
& \text { ديوان الإمام الشافعي، (اعتنى به: عبد الرحمن المصطاوي)، دار المعرفة، } 2005 .
\end{aligned}
$$

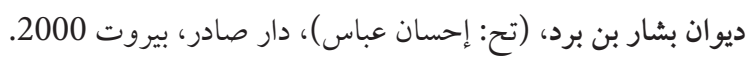

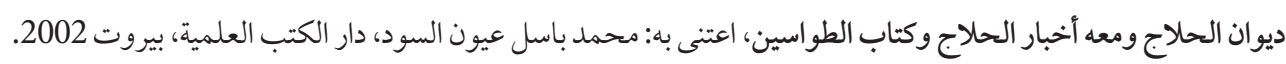

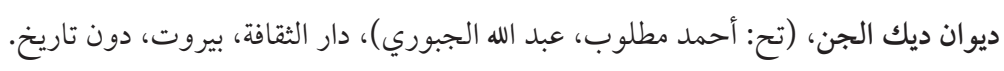
ديوان العباس بن الأحنف، (تح: عاتكة الخزرجي)، مكتة دار الكتب المصرية، القاهرة 1954.

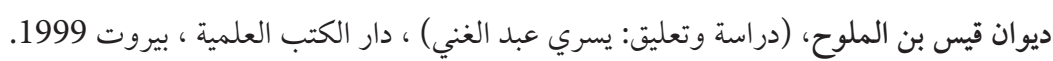

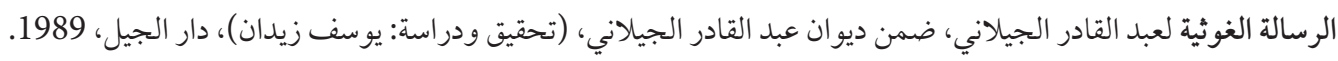

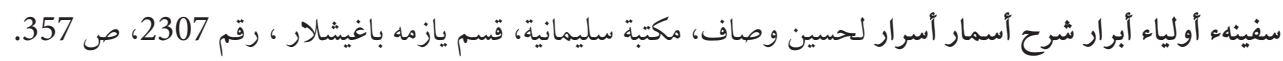

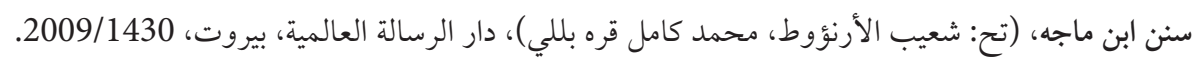

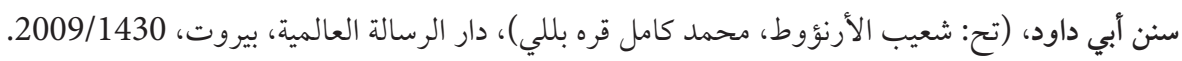
شرح البردة لإبراهيم الباجوري، (تح: عبد الرحمن حسن محمود)، مكتبة الآداب، القاهرة، دون تاريخ.

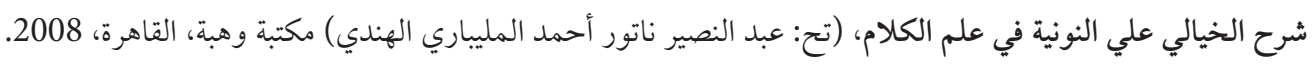


شرح السنة لأبي محمد محيي السنة البغوي، ، (ت: شعيب الأرنؤوط ـ محمد زهير الشاويش)، المكتب الإسلامي، دمشق/ بيروت، 1983.

$$
\text { شرح النووي على صحيح مسلم ، دار إحياء التراث العربي، بيروت } 1392 .
$$

الشقائق النعمانية في علماء الدولة العثمانية، لأحمد بن مصلح الدين طاشكبري زاده، دار الكتاب العربي، بيروت 1975. عرائس البيان في حقائق القرآن لأبي محمد صدر الدين روزبهان البقلي ، (تح: أحمد فريد المجيدي)، دار الكتب العلمية، بيروت 2008.

غرائب القر آن ورغائب الفرقان لنظام الدين القمي النيسابوري، (تح: زكريا عميرات) ، دار الكتب العلمية، بروت 1416. قوت القلوب في معاملة المحبوب ووصف طريق المريد إلى مقام التوحيد لأبي طالب المكي ، (تحقيق: عاصم إبراهيم الكيالي)، دار الكتب العلمية، بيروت 2005/1426.

$$
\text { الكافي لمحمد بن يعقوب الكليني ، منشورات الفجر، بيروت، } 2007 .
$$

كتاب الأعلام بإشارات أهل الإلهام لابن عربي ضمن رسائله، دار صادر، بيروت 1997.

$$
\text { كتاب الحجب لابن عربي، دار الكتب العلمية، بيروت } 2009 .
$$

كشف الخفاء ومزيل الإلباس عما اشتهر من الأحاديث على ألسنة الناس لإسماعيل بن محمد العجلوني، مكتبة القدسي، القاهرة، 1361.

اللمع لأبي السراج (تح: عبد الحليم محمود وطه عبد الباقي سرور)، دار الكتب الحديثة، القاهرة 1960. مثنوي معنوي لجلال الدين الرومي، (به تصحيح رينولد أ. نيكلسون)، انتشارات هرمس، تهران 1390. مراح المعالي في شرح الأمالي لأحمد عاصم أفندي ، استانبول 1304. المستطرف في كل فن مستظرف للإبشيهي، عالم الكتب، بيروت 1419.

مسند أحمد بن حنبل، (تح: شعيب الأرنؤوط - عادل مرشد و آخرون)، مؤسسة الرسالة ، 2001. المسند الصحيح لمسلم بن الحجاج، (تح: محمد فؤاد عبد الباقي)، دار إحياء التراث العربي، بيروت. معاني فصوص الحكم لداود بن محمود القيصري، (اعتنى به عاصم إبراهيم الكيالي)، دار الكتب العلمية، بيروت بدون تاريخ.

المعجم الكبير للطبراني، (تح: حمدي بن عبد المجيد السلفي)، مكتبة ابن تيمية، القاهرة، 1993. مفاتيح الغيب لفخر الدين الرازي، دار إحياء التراث العربي، بيروت 1420.

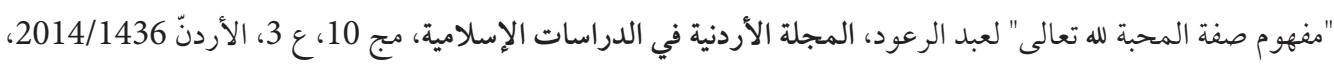
ص وفيات الأعيان وأنباء أبناء الزمان لابن خلكان، (تح: إحسان عباس)، دار صادر، بيروت 1994. 


\section{Kaynakça}

Abbas b. el-Ahnef. Dîvânü'l-Abbas b. el-Ahnef (nşr. Âtike el-Hazrecî). Kahire: Dâru’l-Kütübi'l-Mısriyye, 1954. Abdülahad Nûrî. Abdülahad Nûrî Dîvânı (haz. Ali Osman Çoşkun). Ankara: Milli Eğitim Bakanlı̆̆ı Yayınları: 2001. -------. Abdülahad Nuri ve Divanı: İnceleme ve Tenkitli Metin (haz. Hüseyin Akkaya). Kitabevi: İstanbul, 2003. el-Aclûnî, İsmail b. Muhammed. Keş̧üll-hafâ ve müzîlü'l-ilbâs ammeştehera mine'l-ehâdîs alâ elsineti’n-nâs. Kahire: Mektebetü'l-Kudsî, 1361.

Ahmed b. Hanbel. Müsned (nşr. Şuayb el-Arnaût v.dğr.). I-L. Beyrut: Müessesetü’r-Risâle, 2001.

Asım Ahmed Efendi. Merâhu'l-meâlî̀ fì şerhi'l-Emâlî. İstanbul, 1419.

el-Attâr, Ferîdüddîn. Tezkiretü’l-evliyâ (trc. Muhammed el-Asîlî, nşr. Muhammed Edîb el-Hâdir), Dımaşk: Dâru'l-Mektebî, 2009.

el-Bâcûrî, İbrahim. Şerhu'l-Bürde (nşr. Abdurrahman Hasan Mahmud). Kahire: Mektebetü’l-Âdâb, ts.

el-Baklî, Muhammed Sadruddin Ruzbihân. Arâisu'l-beyân fî hakâiki'l-Kurân (nşr. Ahmed Ferîd el-Mecîdî). Beyrut: Dâru'l-Kütübi'l-İlmiyye, 2008.

Bal, Mehmet Turan. Abdulahad Nurî Sivasînin Hikmetu't-Teâruz Fî Surati't-Tenâkuz Adlı Eseri (yüksek lisans tezi, 2013). Marmara Üniversitesi SBE.

Baz, İbrahim. Abdülahad Nûrî Sivâsî Hayatı Eserleri Görüşleri. İstanbul: İnsan Yayınları, 2007.

el-Begavî, Ebû Muhammed Muhyissünne el-Hüseyn b. Mes'̂ud. Şerhu's-sünne (nşr. Şuayb el-Arnaût Muhammed Züheyr eş-Şâîiş). I-XVI. Dımaşk: el-Mektebü'l-İslâmî, 1983.

Beşşâr b. Bürd. Dîvânu Beşşâr b. Bürd (nşr. İhsan Abbas). Beyrut: Dâr Sâdır, 2000.

el-Beyzâvî, Ebû Saîd Abdullah b. Ömer. Envâru't-tenzîl ve esrâru't-te’vîl (nşr. Muhammed Abdurrahman elMar'aşlî). I-V. Beyrut: Dâru İhyâi't-Türâsi'l-Arabî, 1418.

el-Buhârî, Muhammed b. İsmail. el-Câmi'u’s-sahîh (nşr. Muhammed Züheyr Nâsır en-Nâsır). Beyrut: Dâru Tavkin-Necât, 1422.

Bursalı Mehmed Tahir. Osmanlı Müellifleri (haz. A. Fikri Yavuz - İsmail Özen). İstanbul: Meral Yayınevi, ts. el-Cîlânî, Abdülkadir. er-Risâletü'l-Gavsiyye (nşr. Yusuf Zeydan). Beyrut: Dâru'l-Cîl, 1989.

Demirci, Mustafa. Semâ Risaleleri (yüksek lisans tezi, 1996). Marmara Üniversitesi SBE.

Dîkülcin, Ebu Muhammed Abdüsselam. Dîvânü Dîki'l-Cin (nşr. Ahmed Matlûb - Abdullah el-Cebûrî). Beyrut: Dâru's-Sekâfe, ts.

Ebû Dâvûd, Süleyman b. El-Eşass. Sünen (nşr. Şuayb el-Arnaût - Muhammed Kamil Karabelli). Beyrut: Müessesetü't-Risâleti'l-Âlemiyye, 2009/1430.

Hallâc-1 Mansûr. Dîvânu'l-Hallâc ve méahu ahbâru'l-Hallâc ve Kitâbü't-Tavâsîn (nşr. Muhammed Bâsil Uyûnü’s-sûd). Beyrut: Dâru'l-Kütübi'l-İlmiyye, 2002.

Hayâlî, Şemseddin Ahmed. Şerhu'l-Hayâlî ale’n-nûniyye fî 'ilmi'l-kelâm (nşr. Abdünnasîr Nâtûr el-Melîbârî). Kahire: Mektebetu Vehbe, 2008.

Hüseyin Vassâf. Sefîne-i Evliyâ Şerh-i Esmâr-ı Esrâr. Süleymaniye Kütüphanesi, Yazma Bağışlar Bölümü, no. 2307. el-Isfahânî, Ebû Nuaym Ahmed b. Abdillah. Hilyetü'l-evliyâ ve tabakâtü'l-asfiyâ. I-X. Beyrut: Dâru'lKütübi'l-İlmiyye, 1409.

İbnü'l-Arabî. Muhyiddîn Muhammed b. Ali. Kitâbü’l-A'lâm bi-işârât ehli'l-ilhâm. Beyrut: Dâru Sâdır, 1997. Kitâbü'l-Hucub. Beyrut: Dâru'l-Kütübi'l-İlmiyye, 2009.

İbn Hallikân, Ebü'l-Abbas Şemsüddîn Ahmed. Vefeyâtü'l-a'yân ve enbâu ebnâi'z-zemân (nşr. İhsan Abbas). I-VII. Beyrut: Dâru Sâdır, 1994.

İbn Mâce, Ebû Abdillah Muhammed b. Yezîd. Sünen (nşr. Şuayb el-Arnaût - Muhammed Kâmil Karabelli). Beyrut: Müessesetü’t-Risâleti'l-Âlemiyye, 1430/2009. 
el-İbşîhî, Ebü’l-Feth Bahâüddîn Muhammed. el-Müstetraf fî külli fennin mustazraf. Beyrut: Âlemü’l-Kütüb, 1419. Kays b. el-Mülevvah. Dîvânü Kays b. el-Mülevvah (nşr. Yüsrî Abdülganî). Beyrut: Dâru'l-Kütübỉl-İlmiyye, 1999. el-Kayserî, Davud b. Mahmûd. Meânî Fusûsi'l-hikem (nşr. Âsım İbrahim el-Keyyâlî). Beyrut: Dâru’lKütübi'l-İlmiyye. ts.

el-Kelâbâzî, Muhammed b. İbrahim. et-Ta'arruf li-mezhebi ehli't-tasavvuf (nşr. Ahmed Şemseddin). Beyrut: Dâru'l-Kütübi'l-İlmiyye, 1993.

Kencik, Ali Rıza. Cemâleddin Aksarâyî ve Ona Nispet Edilen "Erba 'ūne Hadīsen” Adlı Eserin Tahkiki (yüksek lisans tezi, 2009). Selçuk Üniversitesi SBE.

el-Kurtubî, Ebû Abdullah Muhammed b. Ahmed. et-Tezkira bi-ahvâli'l-mevtâ ve umûri'l-âhira (nşr. Sadık b. Muhammed b. İbrahim). I-III. Riyad: Dâru'l-Minhâc, 2004.

el-Küleynî, Muhammed b. Ya‘kûb. el-Kâfî̀. I-VIII. Beyrut: Menşûrâtü’l-Fecr, 2007.

el-Mekkî, Ebû Tâlib Muhammed b. Ali. Kûtü'l-kulûb fî muâmeleti'l-mahbûb ve vasfü tarîki'l-mürîd ilâ makâmi't-tevhîd (nşr. Âsım İbrahim el-Keyyâlî), Beyrut: Dâru'l-Kütübi'l-İlmiyye, 1426/2005.

Meymenî, Abdülazîz. Ebü'l-Alâ ve mâ ileyhi. Beyrut: Dâru'l-Kütübi'l-İlmiyye, 1424.

el-Mütenebbî, Ebü’t-Tayyib Ahmed. Dîvânü'l-Mütenebbî. Beyrut: Dâru Beyrut, 1984.

Muhammed Hasan Abdullah. el-Hubb fi't-türâsi'l-Arabî. Kuveyt: Âlemü'l-Kütüb, 1980.

Müslim b. el-Haccâc el-Kuşeyrî. el-Câmi'u's-sahîh (nşr. Muhammed Fuâd Abdülbâkî). I-V. Beyrut: Dâru İhyâi't-Türâsi'l-Arabî, ts.

en-Nablusî, Abdülganî. Itlâku'l-kuyûd şerhu Mirâtiş̧-şuhûd (nşr. Âsım el-Keyyâlî). Beyrut: Mektebetü Kûti'lKulûb, 2017.

en-Nevevî, Ebû Zekeriyya Muhyiddîn Yahya b. Şeref. el-Minhâc fî şerhi Sahîhi Muslim b. Haccâc. Beyrut: Dâru İhyâi't-Türâsi'l-Arabî, 1392.

en-Neysâbûrî, Nizâmüddîn Hasen b. Muhammed. Garâibü'l-Kur'ân ve ragâibü’l-furkân (nşr. Zekeriyya Umeyrât). Beyrut: Dâru'l-Kütübi'l-İlmiyye, 1416.

er-Raûd, el-Abd. "Mefhûmu sifati'l-mahabbe lillâh." el-Mecelletu'l-Ürdüniyye fid-Dirâsâti'l-İslâmiyye, 1436/2014, X, sy. 3, s. 164-9.

er-Râzî, Fahruddîn Muhammed b. Ömer. Mefâtîhu'l-gayb. Beyrut: Dâru İhyâi't-Türâsi'l-Arabî, 1420.

er-Rûmî, Celâleddîn. Mesnevî̀-i ma'nevî (haz. Reynold Nicholson). Tahran: İntişââ̂t Hermes, 1390.

es-Serrâc, Ebû Nasr Abdullah b. Ali. el-Luma' (nşr. Abdülhalîm Mahmud - Taha Abdülbâkî Surûr). Kahire: Dâru'l-Kütübi'l-Hadîse, 1960.

es-Suyûtî, Celâlüddîn. el-Câmi u's-sağîr. Beyrut: Dâru'l-Kütübi'l-İlmiyye, 2004.

eş-Şâfiî, Muhammed b. İdris. Dîvânü’l-İmâmiş’Şâfî̀ (nşr. Abdurrahman el-Mastâvî). Beyrut: Dâru'l-Ma'rife, 2005.

Şeyhzâde, Muslihiddin Mustafa. Hâşiye ale’l-Beyzâvî. İstanbul: Mektebetü’l-Hakîka, 1998.

et-Taberânî, Süleyman b. Ahmed. el-Mu'cemü’l-kebîr (nşr. Hami b. Abdülmecîd es-Selefî), Kahire: Mektebetü İbn Teymiyye, 1993.

Taşköprîzâde, Ahmed b. Muslihuddîn. eş-Şekâiku’n-nu'mâniyye fî ulemâi'd-devleti'l-Usmâniyye. Beyrut: Dâru'l-Kitâbi'l-Arabî, 1975.

Türer, Osman. Muhammed Nazmi ve Hediyyetüll-İhvân’ (doktora tezi, 1982). Ankara Üniversitesi SBE.

Uçman, Abdullah. "Abdülahad Nûrî." DİA, I, 178-9.

Yılmaz, Necdet. Abdülahad Sîvâsî ve Mirâtüll-Vücûd ve Mirkâtu’ş-şuhûd Alı Eseri (yüksek lisans tezi, 1993). Marmara Üniversitesi SBE.

Yılmaz, Okan Kadir. İSAM Tahkikli Neşir Kılavuzu. Ankara: İSAM, 2020.

ez-Ziriklî, Hayruddîn. el-A'lâm: Kâmûs terâcim li-eşheri'r-ricâl ve’n-nisâ mine'l-Arab ve'l-müsta'ribîn ve'lmüsteşrikîn. Beyrut: Dâru'l-İlm li'l-Melâyîn, 2002. 